
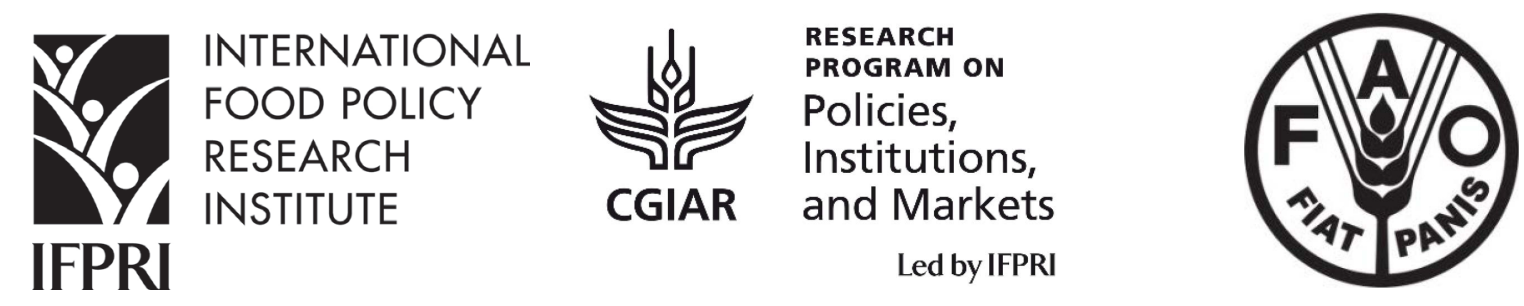

IFPRI Discussion Paper 01340

April 2014

\title{
How Does Climate Change Alter Agricultural Strategies to Support Food Security?
}

\author{
Philip Thornton \\ Leslie Lipper
}

CGIAR Research Program on Policies, Institutions, and Markets 


\section{INTERNATIONAL FOOD POLICY RESEARCH INSTITUTE}

The International Food Policy Research Institute (IFPRI), established in 1975, provides evidence-based policy solutions to sustainably end hunger and malnutrition and reduce poverty. The Institute conducts research, communicates results, optimizes partnerships, and builds capacity to ensure sustainable food production, promote healthy food systems, improve markets and trade, transform agriculture, build resilience, and strengthen institutions and governance. Gender is considered in all of the Institute's work. IFPRI collaborates with partners around the world, including development implementers, public institutions, the private sector, and farmers' organizations, to ensure that local, national, regional, and global food policies are based on evidence.

\section{CGIAR RESEARCH PROGRAM ON POLICIES, INSTITUTIONS, AND MARKETS}

The CGIAR Research Program on Policies, Institutions, and Markets (PIM) leads action-oriented research to equip decisionmakers with the evidence required to develop food and agricultural policies that better serve the interests of poor producers and consumers, both men and women. PIM combines the resources of CGIAR centers and numerous international, regional, and national partners. The program is led by the International Food Policy Research Institute (IFPRI). www.pim.cgiar.org

CGIAR is a global agriculture research partnership for a food secure future. Its science is carried out by the 15 research centers that are members of the CGIAR Consortium in collaboration with hundreds of partner organizations. www.cgiar.org

\section{AUTHORS}

Philip Thornton (p.thornton@cgiar.org) is a research theme leader of the CGIAR Research Program on Climate Change, Agriculture and Food Security (CCAFS), International Livestock Research Institute, Nairobi, Kenya

Leslie Lipper is a senior environmental economist in the Agriculture and Development Economics Division of FAO, Rome.

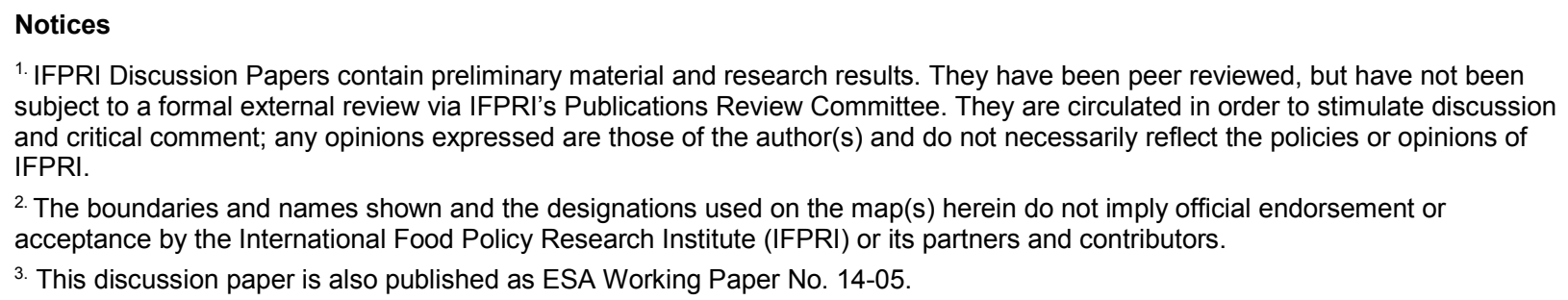

Copyright 2014 International Food Policy Research Institute and Food and Agriculture Organization of the United Nations (FAO). All rights reserved. Sections of this material may be reproduced for personal and not-for-profit use without the express written 
permission of but with acknowledgment to IFPRI and FAO. To reproduce the material contained herein for profit or commercial use requires express written permission. To obtain permission, contact the IFPRI Communications Division at ifpri-copyright@cgiar.org. 


\section{Contents}

Abstract iv

Acknowledgments $\quad$ vi

Abbreviations and Acronyms vii

1. Introduction 1

2. Expected Impacts of Climate Change on Agriculture 2

3. Potential Responses to Climate Change Impacts on Agriculture 7

4. The Roles of CGIAR and FAO in Supporting Needed Transitions 13

5. Monitoring and Evaluation 24

6. Conclusions: Suggested Priority Actions for FAO and CGIAR 29

References $\quad 31$ 


\section{Tables}

3.1 Examples of adaptation strategies and institutions for risk transfer under climate change 12

5.1 Example of food system change metrics 26

\section{Figure}

2.1 Estimated evolution to 2020 of greenhouse gas emissions from agricultural production by region, excluding land-use change and energy used in agriculture

\section{Boxes}

4.1 Climate change brings challenges for crop breeding in CGIAR

4.2 Building youth networks to support innovation

$4.3 \mathrm{New}$ ways of getting information to (and from) farmers

4.4 Audio conferring for extension service delivery in Ghana 


\begin{abstract}
The negative effects of climate change are projected to affect the populations with the least capacity to adjust, but with the greatest need for improved agricultural performance to achieve food security and reduce poverty. The purpose of the paper is to identify how climate change affects how we should approach the process of transforming agricultural systems (including crops, livestock, fisheries and forestry) to support global food security and poverty reduction in a sustainable way. We also identify implications for FAO (Food and Agriculture Organization of the United Nations) and CGIAR priorities.

To achieve this goal, we identify and discuss five major categories of responses within agricultural transitions that can be taken to respond to climate change: 1) increasing the resilience of production systems, 2) diversification, 3) expanding the use of no regrets technologies and planning, 4) better use of information for risk management, and 5) utilizing the co-benefits from mitigation. The urgency of reducing food insecurity together with the need for immediate responses to climate change impels us to define mechanisms, actions and approaches to stimulate desired transitions.

We also identify four categories of priority actions that FAO and CGIAR can take to facilitate actions amongst stakeholders from farm to national and international level. These include: 1) developing and promoting agricultural technologies and innovations; 2) strengthening local institutions; 3) achieving coordinated and informed policies; and 4) increasing access to financing. Both FAO and CGIAR are undergoing reform processes to improve the effectiveness of their respective work programs. A fundamental aspect of this reform is moving to the use of results-based frameworks, which require the development of indicators for tracking progress towards stated objectives. Climate change affects the nature of the indicators we need to monitor effective progress towards meeting the two organizations objectives, and these are discussed. We conclude by identifying three main priority areas of action for the CGIAR and FAO in order to better meet the objectives of achieving sustainable agriculture and food security under the conditions climate change imposes: enhancing our understanding of how climate change impacts agriculture; developing tools and assessments for evaluating options; and promoting innovation and linking knowledge with action.
\end{abstract}

Keywords: climate smart; adaptation; mitigation; transformation; monitoring and evaluation 


\section{ACKNOWLEDGMENTS}

This paper was originally produced as an invited background paper for the conference "Food Security Futures: Research Priorities for the 21st Century", co-facilitated by the CGIAR Research Program on Policies, Institutions, and Markets (PIM), led by IFPRI, and the Food and Agricultural Organization (FAO), and which was held on April 11-12, 2013, in Dublin, Ireland. Three other background papers were produced for this conference: "Public Sector Agricultural Research Priorities for Sustainable Food Security: Perspectives from Plausible Scenarios" by Gerald Nelson and Dominique van der Mensbrugghe; "Priorities for Public Sector Research on Food Security and Nutrition" by Howarth Bouis, Terri Raney and John McDermott; and "Food Security and Sustainable Resource Use: What are the Resource Challenges to Food Security?" by Frank Place and Alexandre Meybeck. We thank several reviewers for constructive comments on an earlier version.

Funding support for the conference and the underlying study for this paper was provided by the CGIAR Research Program on Policies, Institutions, and Markets, with contribution from the CGIAR Research Program on Climate Change, Agriculture and Food Security (CCAFS).

The authors would like to acknowledge the contributions of the following research collaborators: Stephen Baas (Climate, Energy and Tenure Division, FAO), Andrea Cattaneo (Senior Economist, Agriculture and Development Economics Division, FAO), Sabrina Chesterman, Kevern Cochrane (Rhodes University), Cassandra de Young (Fishery Policy Analyst, Fisheries and Aquaculture Economics and Policy Division, FAO), Polly Ericksen (Team Leader, International Livestock Research Institute), Jacob van Etten, (Theme Leader, Adaptation to Climate Change, Bioversity), Fabrice de Clerck (Leader, Agrobiodiversity and Ecosystem Services Programme, Bioversity), Boru Douthwaite (Innovation and Impact Director, WorldFish), Ashley DuVal, Carlo Fadda (Theme leader, Productive Agricultural Ecosystems, Bioversity), Tara Garnett (Researcher, Food Climate Research Network, Environmental Change Institute, University of Oxford), Pierre Gerber (Livestock Policy Office, Animal Production and Health, FAO), Mark Howden (Theme Leader, Adaptive Primary Industries, Enterprises and Communities, CSIRO), Wendy Mann (Senior Policy Advisor, Agriculture and Development Economics Division, FAO), Nancy McCarthy (Senior Researcher, LEAD Analytics Inc.), Reuben Sessa (Natural Resources Officer (Climate Change), Climate, Energy and Tenure Division, FAO), Sonja Vermeulen (Science Director, CGIAR Research Program on Climate Change, Agriculture and Food Security [CCAFS]), Joost Vervoort (Scenarios Officer, CCAFS). 


\section{ABBREVIATIONS AND ACRONYMS}

Ag R4D agricultural research for development

CCAFS CGIAR Research Program on Climate Change, Agriculture, and Food Security

CFS Committee on World Food Security

CRP CGIAR research program

CSA climate-smart agriculture

FAO Food and Agriculture Organization of the United Nations

GEF Global Environment Facility

GHG greenhouse gas

GLOBIOM Global Biosphere Management Model

HLPE high level panel of experts

ICT information and communications technology

IDO intermediate development outcome

IMPACT International Model for Policy Analysis of Agricultural Commodities and Trade

M\&E monitoring and evaluation

MICCA Mitigation of Climate Change in Agriculture

NARO National Agricultural Research Organization

NGO nongovernmental organization

SLO system-level outcome

SSA Africa south of the Sahara

SYFN Savannah Young Farmers Network

UNFCCC United Nations Framework Convention on Climate Change 



\section{INTRODUCTION}

In this paper we focus on how climate change affects the way that agricultural systems and the people that manage and govern them need to change in the next 20 years in order to achieve food security, and how the Food and Agriculture Organization of the United Nations (FAO) and CGIAR can support that change. We build on a huge body of literature on sustainable agricultural development and intensification, as well as work on nutrition security and resource-use efficiency, much of which is articulated in other papers in this conference.

As the results presented in Nelson and van der Mensbrugghe (2013) indicate, climate change is expected to have generally negative effects on developing-country agriculture, with concomitant implications for food security. Projections indicate that the impacts will increase over time, with socioeconomic development and trade much more important drivers of food security in the short run, but with climate change playing an increasingly important role after 2030. In the intervening years, however, climate shocks such as drought, flooding, and extreme temperatures are expected to increase in frequency and intensity, and that is already occurring (IPCC 2012). In the absence of measures to reduce the vulnerability to, and impacts of, such extreme events, they can be expected to generate significant and negative impacts on food security (FAO 2010; Foresight 2011).

At present, some 70 percent of the food-insecure people in the world are rural and directly or indirectly dependent on agriculture for income as well as food (IFAD 2011). Rural poverty and hunger are concentrated in two locations: South Asia, with the greatest number of poor rural people, and Africa south of the Sahara (SSA), with the highest incidence of rural poverty. Those two areas are also where the bulk of future population growth is expected to occur. Some countries, mostly in SSA, could see population increases of 200 percent or more to the middle of this century, representing a substantial growth in absolute numbers (Nelson and van der Mensbrugghe 2013). Such areas of growing populations, highly dependent on agriculture and with high rates of food insecurity, are also where climate change is expected to have the worst effects. Ericksen et al. (2011) indicate considerable overlap between areas of high poverty and food insecurity and "climate change hotspots," partly due to projected impacts of climate change but also because poverty reduces coping capacity.

Reducing poverty and food insecurity in agriculture-dependent populations is thus also a key means of reducing vulnerability to climate change, increasing the urgency of addressing the challenge. How to accomplish that goal? Research has shown that gross domestic product growth originating in agriculture is almost three times more effective in reducing poverty than growth in other sectors of the economy due not only to the direct poverty reduction effect but also to its potentially strong growth linkage effects on the rest of the economy (FAO 2012b; De Janvry and Sadoulet 2010). Thus, the next 20 years are a critical window of time for accelerating the rate of agricultural growth in least-developed countries to achieve food security and development for agriculture-dependent populations.

Climate change fundamentally alters the constraints and opportunities for transforming agricultural systems. The increased frequency and intensity of climate shocks is already mandating greater attention to resilience in production and social systems and better means of risk management. Uncertainty about the scale and nature of changes that climate change will impose affects the way we approach planning and investment. Climate change gives rise to a need to avoid maladaptation and thus the importance of identifying no-regrets strategies in the short run, as greater information about the effects of climate change can be obtained. The significant increases in emissions that could be expected under conventional agricultural growth strategies, associated with efficiency losses, mandate a major shift in focus to increasing resource-use efficiency as a basis for achieving needed growth. The following sections of this paper provide evidence on the projected impacts of climate change on agricultural systems and the implications they have for the way we develop and implement strategies of sustainable agricultural growth for food security. The paper concludes with a discussion of the roles of FAO and CGIAR in promoting needed changes. 


\section{EXPECTED IMPACTS OF CLIMATE CHANGE ON AGRICULTURE}

\section{What We Know about the Threats of Climate Change to Agricultural Production Systems ${ }^{1}$}

Climate change may affect agricultural and natural systems in many ways. In general, higher average temperatures will accelerate the growth and development of plants. As for livestock, most species have comfort zones between 10 and 30 degrees Celsius $\left({ }^{\circ} \mathrm{C}\right)$, and at temperatures above that, animals reduce their feed intake 3 to 5 percent per additional degree of temperature. Rising temperatures are not uniformly bad: they will lead to improved crop productivity in parts of the tropical highlands, for example, where cool temperatures are currently constraining crop growth. Average temperature effects are important, but there are other temperature effects too. Increased night-time temperatures have negative effects on rice yields, for example, by up to 10 percent for each $1{ }^{\circ} \mathrm{C}$ increase in minimum temperature in the dry season. Increases in maximum temperatures can lead to severe yield reductions and reproductive failure in many crops. In maize, for example, each degree day spent above $30^{\circ} \mathrm{C}$ can reduce yield by 1.7 percent under drought conditions.

Climate change is already affecting rainfall amounts, distribution, and intensity in many places. This has direct effects on the timing and duration of crop growing seasons, with concomitant impacts on plant growth. Rainfall variability is expected to increase in the future, and floods and droughts will become more common. Changes in temperature and rainfall regime may have considerable impacts on agricultural productivity and on the ecosystem provisioning services provided by forests and agroforestry systems on which many people depend. There is little information currently available on the impacts of climate change on biodiversity and subsequent effects on productivity in either forestry or agroforestry systems.

Climatic shifts in the last few decades have already been linked to changes in the large-scale hydrological cycle. Globally, the negative effects of climate change on freshwater systems are expected to outweigh the benefits of overall increases in global precipitation due to a warming planet.

The atmospheric concentration of carbon dioxide $\left(\mathrm{CO}_{2}\right)$ has risen from a preindustrial 280 parts per million to approximately 400 parts per million, and was rising by about 2 parts per million per year during the last decade. Many studies show a beneficial effect $\left(\mathrm{CO}_{2}\right.$ fertilization) on some crops (those that utilize a $\mathrm{C}_{3}$ photosynthetic pathway) but limited if any effect on other plants such as maize and sorghum that utilize $\mathrm{a} \mathrm{C}_{4}$ photosynthetic pathway. There is some uncertainty associated with the impact of increased $\mathrm{CO}_{2}$ concentrations on plant growth under typical field conditions, and in some crops such as rice, the effects are not yet fully understood. Whereas increased $\mathrm{CO}_{2}$ has a beneficial effect on wheat growth and development, for example, it may also decrease the protein concentration in the grain. In some crops such as bean, genetic differences in plant response to $\mathrm{CO}_{2}$ have been found, and these could be exploited through breeding. Increased $\mathrm{CO}_{2}$ concentrations lead directly to ocean acidification, which (together with sea-level rise and warming temperatures) is already having considerable detrimental impacts on coral reefs and the communities that depend on them for their food security.

Many of the impacts of climate change on agriculture will be mediated through water. The global demand for water withdrawals by agriculture are projected to increase by 11 percent to 2050 (Bruinsma 2009), and climate change adds serious challenges to the water security problem. Freshwater resources are already relatively scarce, amounting to only 2.5 percent of all water resources (Millennium Ecosystem Assessment 2005). While groundwater supplies between 1.5 and 3 billion people with water for drinking, in some regions water tables are already declining (Rodell, Velicogna, and Famiglietti 2009). The increasing human population will clearly add to the demand for water for nonagricultural and agricultural use, not only for staple crops but also in the production of livestock feed for rapidly increasing livestock populations. Although a warming world will result in more rainfall globally, the distribution of that rainfall, while uncertain, is likely to be highly variable, but we know that many parts of the tropics and subtropics are likely to be particularly affected by reduced rainfall amounts. By 2050, more than half the

\footnotetext{
${ }^{1}$ Much of this section is from Thornton and Cramer (2012).
} 
world's population will live in countries with severe water constraints, including China, Egypt, Ethiopia, India, Iran, Jordan, and Pakistan (Rockström et al. 2009).

Little is known, in general, about the impacts of climate change on the pests and diseases of crops, livestock, and fish, but they could be substantial. Yam and cassava are crops that are both well adapted to drought and heat stress, but it is thought that their pest and disease susceptibility in a changing climate could severely affect their productivity and range in the future. Potato is another crop for which the pest and disease complex is very important - similarly for many dryland crops - and how climate change (including the problems associated with increased rainfall intensity) may affect that is not well understood. Climate change will result in multiple stresses for animals and plants in many agricultural and aquatic systems in the coming decades. In rice, there is some evidence that a combination of heat stress and salinity stress leads to additional physiological effects over and above the effects that each stress has in isolation. In general, much is unknown about how stresses may combine in agricultural and aquacultural systems in the face of climate change.

The impacts of changes in climate and climate variability on agricultural production will have substantial effects on smallholder and subsistence farmers, pastoralists, and fisherfolk in many parts of the tropics and subtropics. Crop yields in SSA are likely to be particularly adversely affected, and the resulting reduced food security potentially will increase the risk of hunger and undernutrition (HLPE 2012).

In summary, there is still considerable uncertainty as to the likely impacts of climate change at the detailed geographic scales necessary to help specific farmers adapt. With further development and refinement of climate and agricultural models in the next 15 years, answers to this question should become clearer. In the meantime we know that extreme events are increasing. Those two factors give rise to a set of possible response measures outlined in Section 3.

\section{Potential Effects of Agricultural Growth in Developing Countries on Climate Change}

Globally, agriculture contributes 30 to 40 percent of anthropogenic greenhouse gas (GHG) emissions. Emission reductions by rich countries alone will not be enough to limit warming to tolerable levels. Although cumulative per capita emissions have been small not only in low-income but also in middleincome countries, total annual energy-related $\mathrm{CO}_{2}$ emissions in middle-income countries have now caught up with those of rich countries, and the largest share of current emissions from land-use change comes from tropical countries. Significant emissions growth is projected for developing countries.

Three-quarters of agricultural GHG emissions occur in developing countries, and this share may rise above 80 percent by 2050 as nearly all agricultural emissions growth under business as usual will occur in developing countries (Smith et al. 2008). As conventionally counted, reported emissions from land-use change all result from conversion of tropical forest and tropical peat lands to other uses. In nearly all cases, these uses will be agricultural, although data challenges sometimes make this difficult to show. The developing world is therefore the focus of agricultural GHG emissions. Figure 2.1 shows estimates of emissions from production by region (excluding land-use change and energy used in agriculture). Total emissions from livestock over the period 1995-2005 were between 5.6 and 7.5 billion metric tons of $\mathrm{CO}_{2}$ equivalent $\left(\mathrm{GtCO}_{2} \mathrm{eq}\right)$ per year (Herrero et al. 2014). The most important sources of emissions were enteric methane (1.6-2.7 $\left.\mathrm{GtCO}_{2} \mathrm{eq}\right)$, nitrous oxide $\left(\mathrm{N}_{2} \mathrm{O}\right)$ emissions associated with feed production $\left(1.7 \mathrm{GtCO}_{2} \mathrm{eq}\right)$, and land use for animal feed and pastures, including change in land use (1.6 $\mathrm{GtCO}_{2} \mathrm{eq}$ ). The developing world contributes to 70 percent of emissions from ruminants and 53 percent of emissions from monogastrics, and that share is expected to grow as livestock production increases in the developing world to meet demand increases. Mixed crop-livestock systems dominate livestock emissions (58 percent of total emissions), while grazing-based systems contribute 19 percent. Industrial and other systems make up the rest. 
Figure 2.1 Estimated evolution to 2020 of greenhouse gas emissions from agricultural production by region, excluding land-use change and energy used in agriculture

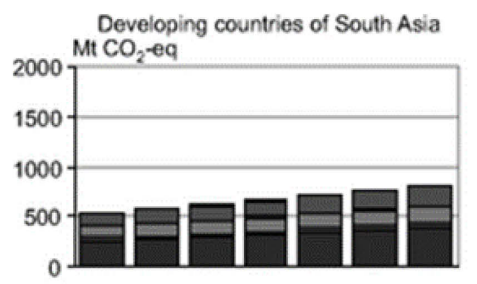

Developing countries of East Asia
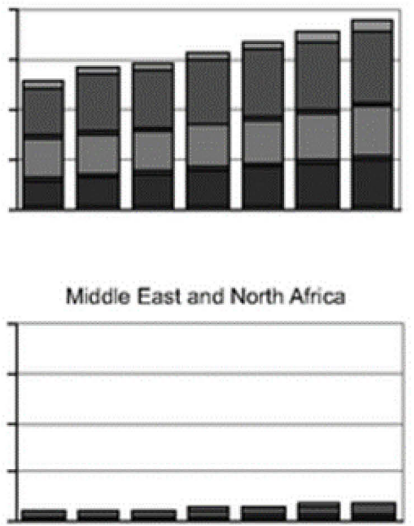

Central and Eastern Europe

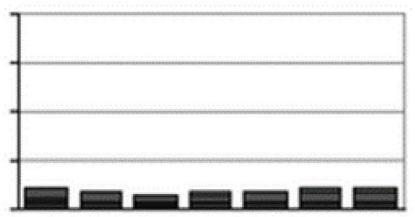

Developing regions
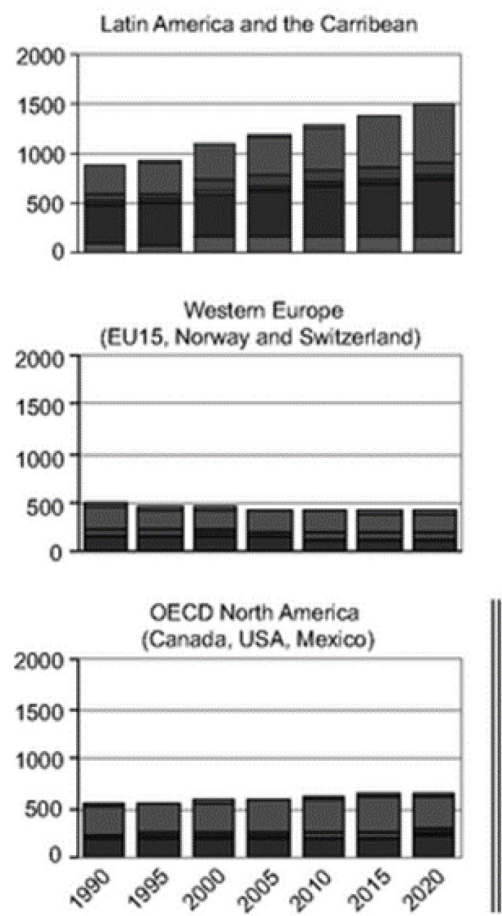

Westem Europe
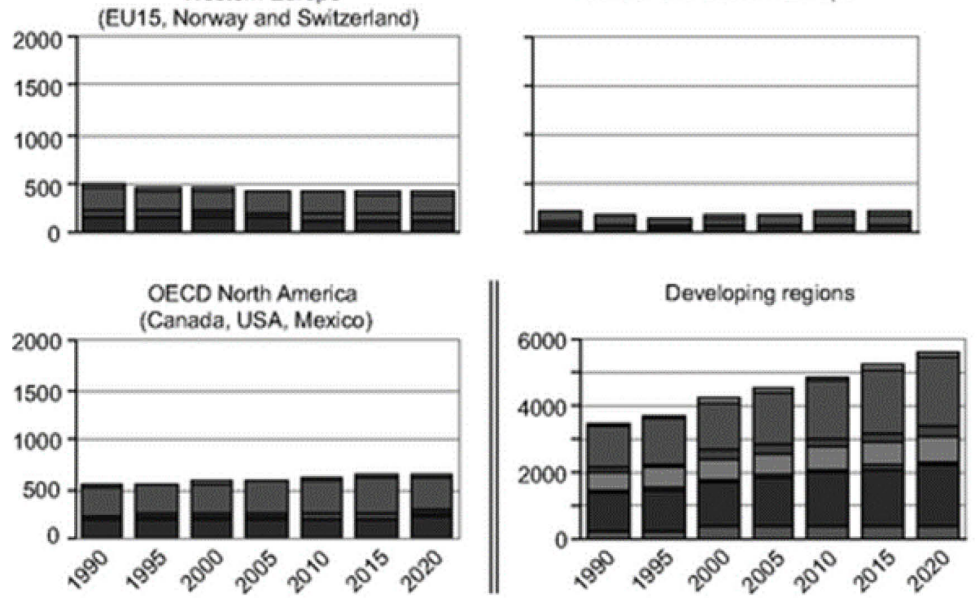

Sub-Saharan Africa

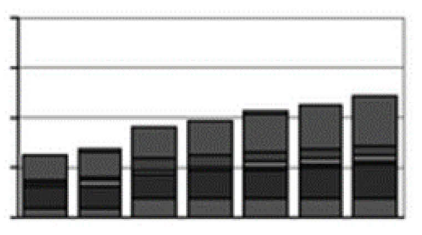

- $\mathrm{N}_{2} \mathrm{O}$ Manure

口 $\mathrm{N}_{2} \mathrm{O}$ Soils

घ $\mathrm{N}_{2} \mathrm{O}$ Burning

$\square \mathrm{CH}_{4}$ Rice

a $\mathrm{CH}_{4}$ Manure

a $\mathrm{CH}_{4}$ Enteric

口 $\mathrm{CH}_{4}$ Buming
Caucasus and Central Asia

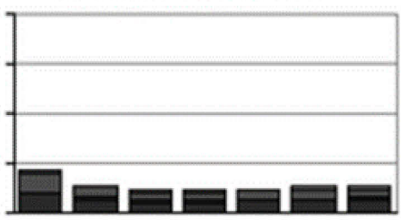

OECD Pacific (Australia, New Zealand, Japan, Korea)

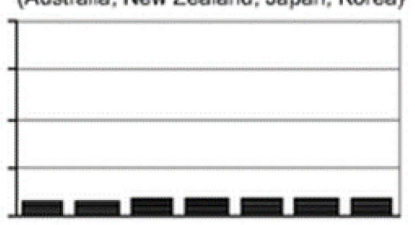

Developed regions

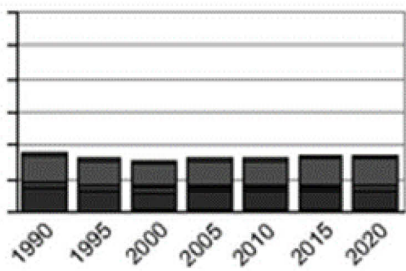

Source: Popp et al. (2010).

Future trends in land-use change may have enormous impacts on GHG emissions. Rapid conversion of forests and other natural habitats to cropland and pastures has occurred over the last 150 years. The underlying driving forces of deforestation are highly heterogeneous, and the representation of those drivers in global integrated assessments is still rudimentary. Nevertheless, several scenarios of the future envisage continuing decline in natural forest areas in regions such as Latin America and SSA (Rosegrant et al. 2009; van Vuren et al. 2009). Under those same scenarios, some cropland expansion will occur, although only limited increases in pasture land, and grazing systems will increasingly provide ecosystem goods and services through situation-specific restoration or intensification, or both. In many cases intensive agricultural systems will face increasing resource pressures in many regions of the developing world, to which various responses are possible. However, those generally involve improving resource-use efficiency, which can also moderate GHG emissions (Herrero et al. 2010).

Reducing deforestation through agricultural intensification strategies that involve not only increased yields but also reduction of incentives for agricultural expansion offers considerable potential. In general, if a hectare of forest can be saved by yield gains or a hectare of land can be reforested because of yield gains, there would be large carbon gains. Increasing yields through increases in fertilizer would reduce emissions substantially compared to the alternative of clearing more land to provide the same food (Burney, Davis, and Lobell 2010). 
Increasing competition for land in the future will also come from biofuels. Future scenarios of bioenergy use vary widely (van Vuren et al. 2009), and there are considerable evidence gaps still concerning the likely trade-offs between food, feed, and fuel in production systems in both developed and developing countries, particularly related to second-generation bioenergy technology.

Some GHG emissions are largely related to inefficiencies in production systems, and so increasing efficiency is both a key development and a key mitigation strategy. In ruminant livestock herds, for example, a large share of the enteric methane emissions may come from the breeding and maintenance overhead, the part of animals that are not in production (milked or fattened) but dedicated to maintain and replace the herd. Methane losses from manure also represent a loss of energy from the system, although these can be recovered when wastes are fed to a biogas digester.

Emissions of $\mathrm{N}_{2} \mathrm{O}$ (direct and indirect) from manure storage and processing amount to some 678 metric tons of $\mathrm{CO}_{2}$ eq, while manure $\mathrm{N}_{2} \mathrm{O}$ emissions (direct and indirect) from manure application on crops and application on pasture amount to 1,499 metric tons of $\mathrm{CO}_{2} \mathrm{eq}(\mathrm{FAO} 2013)$. For $\mathrm{CO}_{2}$, energy consumption along the supply chain contributes a significant share of emissions, especially in monogastric production systems, where they can represent up to 40 percent of emissions in chicken production (FAO 2013). Increasing fertilizer-use efficiency would generate not only mitigation benefits but also higher marginal returns to fertilizer use - an important contribution to increasing farm returns. Energy-use efficiency can be improved in many systems.

The agricultural sector is unique in having the capacity to mitigate by increasing the absorption of GHG emissions in biomass through above- and below-ground sequestration. Increasing soil carbon sequestration in agricultural systems has the largest technical and economic potential for mitigation from the agricultural sector (Smith et al. 2008). Changes in agricultural systems that enhance sequestration such as adoption of improved soil and watershed management practices, agroforestry, and restoration of degraded grazing lands can also have positive impacts on the level and stability of agricultural production (FAO 2009). In croplands, improved agronomic practices that also result in improving agricultural production have generally held out the most hope for soil carbon buildup through changed agricultural management practices. Increasing trees in agricultural landscapes through agroforestry is another potential means of increasing sequestration that also offers important adaptation benefits.

The mitigation options we have discussed fall into the category of supply-side interventions, which reduce net emissions from the agricultural sector through changes in agricultural and forestry management (Smith et al. 2013). In contrast, demand-side measures reduce emissions by changing the character of food and fiber demand. This can be accomplished through reducing wastage in food chains, as well as changing dietary patterns. Smith et al. (2013) argue that whereas supply-side measures may involve trade-offs between food security and mitigation, demand-side measures contribute positively to both objectives. In addition, the net emission reduction potential of the latter is significantly larger. They conclude that both types of measures are needed given the magnitude of mitigation required, with supplyside measures more feasible in the short run, as changing policies and behavior to achieve demand-side reductions will require some transition period. Given the time frame and agricultural-sector focus of this paper, supply-side measures are most relevant, but demand-side measures could have significant impacts on agricultural systems in developing countries in the medium to long term.

There is a strong case to be made for early action on mitigation, due to higher costs of delayed action in meeting chosen mitigation targets, as well as the additional costs of adaptation and response to climate shocks of increasing intensity and magnitude. Delaying mitigation actions in developing countries until 2050 could more than double the total cost of meeting a particular target; and an international agreement that covers only the five countries with the highest total emissions (covering two-thirds of emissions) would triple the cost of achieving a given target, compared with full participation (World Bank 2010).

At the same time, the issue of the developing countries' role in mitigation is a subject of much political debate. This has been the case within negotiations on agriculture, given the sector's importance to benefits beyond carbon: food security, poverty reduction, and economic development. A key principle of the United Nations Framework Convention on Climate Change (UNFCCC) is "common but 
differentiated responsibility," which implies that imposing equal burdens for addressing climate change on developing and developed countries is unfair. The recent Subsidiary Body for Scientific and Technological Advice conclusions on agriculture focus exclusively on adaptation in terms of future work. However, at the country level in developing countries there is some appetite to implement mitigation measures, and within-negotiation discussion of nationally appropriate mitigation actions and how to pursue them has taken place.

Another principle, not specifically articulated in the UNFCCC, is that of climate justice. It "links human rights and development to achieve a human-centered approach, safeguarding the rights of the most vulnerable and sharing the burdens and benefits of climate change and its resolution equitably and fairly" (MRF 2013). Although such principles tend to have greater importance at the international level, they can also influence developing-country attitudes to agricultural mitigation at the country level, where an understanding of context-specific potential trade-offs between food security, adaptation, and mitigation is required, as is the prioritization of food security and consequently necessary adaptation for agricultural transitions, with mitigation as a potential co-benefit. This also implies the need for financial transfers for the provision of mitigation benefits to the global community, an issue addressed in Section 3. 


\section{POTENTIAL RESPONSES TO CLIMATE CHANGE IMPACTS ON AGRICULTURE}

\section{Coping with Uncertainty in Developing Responses}

There is still considerable uncertainty about the scale and eventual nature of adaptation needed to address climate change. This uncertainty has important implications for developing adaptation strategies that will be realized in the future.

Adaptations to climate change can be thought of as incremental changes to existing systems or more systemic changes that bring new components to (or remove old components from) systems, often with the goal of increasing diversification and hedging against new, unknown risk. These are part of a spectrum of levels of adaptation to climate changes. They are not unreasonable as first adaptation steps as they build from existing infrastructure, practice, technologies, and knowledge, largely fit within existing institutional arrangements, often conform to cultural and social norms, are reasonably quick and easy for farmers to evaluate, and involve limited risk, investment, and complexity to manage (Rickards and Howden 2012). However, various analyses suggest that such adaptations will become less effective above temperature increases of $2{ }^{\circ} \mathrm{C}$ (Easterling et al. 2007; Howden et al. 2007; Challinor et al. 2014), requiring further, transformative adaptation (Howden, Crimp, and Nelson 2010; Kates, Travis, and Wilbanks 2012). Furthermore, in countries with strongly climate-affected agriculture such as Australia, there are already examples of agricultural industries and enterprises making more transformative adaptations in response to existing climate changes or perceptions of future changes (Park et al. 2012). In such cases, transformational adaptation has been as much about seeking opportunity as in avoiding threats. Hence these adaptations are intended to be low-regrets strategies. They are characterized by changes in goal (resulting, for example, in a major change in land use or employment) or location (of an agricultural activity or farmers), or both.

Transformational change in agriculture is not new: the planting of biofuel crops instead of food crops, the replacement of subsistence-based agriculture with modern, science-based agriculture, or migration in the face of extreme drought being a few examples among many (Rickards and Howden 2012). What does seem new is that transformational adaptations to climate change are being made proactively with at least a partial recognition of the intersection of climate drivers with broader change processes, in the landscape and socioeconomically, technically and politically. Large-scale changes often incur additional risk and cost, and given uncertainties in trajectories of future climate change, transformational adaptation may be maladaptive or may be seen as over-adapting. This may be particularly so given the long lead times and uncertainty associated with climate change. There is at least one case in Australia where the transformative adaptation has been reversed (Jakku et al. 2014). Consequently, transformational adaptation has been framed as not a single step but rather a continuing process that may reverse, or may be normed and then undergo incremental change before being further transformed (Park et al. 2012). Key costs that need to be considered for transformational adaptation include transaction costs (that is, the toll on resources - mental, emotional, physical, financial, socialthat the process of change exacts), opportunity costs (including those associated with path dependency), and costs of unintended consequences (Rickards and Howden 2012).

Transformative adaptation is likely to occur more successfully with farmers, industry, and regions that have significantly greater adaptive capacity, particularly managerial capacity (Park et al. 2012). Building such capacities may be one area where policy can enhance prospects for transformation, providing an environment where the vision of adaptation to climate change is not limited by the agricultural system as it is now, but rather how it could be. 


\section{Sustainably Intensifying Agricultural Production Systems}

A key defining principle for agricultural technologies and innovations to support food security and poverty reduction in much of the recent literature is the need for sustainable agricultural intensification (Garnett and Godfray 2012; FAO 2012b, 2012c, 2011; Foley et al. 2011; Foresight 2011). Building on that literature with the analysis presented in Section 2, we posit the following as major principles for sustainable agricultural intensification under climate change:

- Although the causes of hunger and malnutrition are various and not a simple challenge of increasing supply, some increases in food output will be needed in coming years as populations grow and diets change.

- Increased production will need to be achieved mostly without bringing new land into agriculture. In many cases no land is available for agricultural expansion; furthermore, in the context of climate change, land-use conversion to agriculture is a major source of emissions (as well as loss of biodiversity).

- Increasing the stability of agricultural production systems requires much greater attention to building ecosystem services that increase resilience (FAO 2012c, 2012d).

- Improving the efficiency of agricultural production systems, increasing sequestration, and reducing waste are not only important forms of mitigation - they may also generate higher and more stable returns.

- If yields are to increase sustainably, we need to harness and develop the knowledge and insights gained from all current systems of agricultural production, including those based on organic principles, local indigenous knowledge, and innovative plant-breeding technologies.

Sustainable agricultural intensification implies a need for better understanding and use of ecosystem services to complement the use of external inputs and how this varies across different agroecologies (FAO 2011). In addition, it implies a need for more knowledge-intensive systems of agricultural management that tap into both traditional and science-based sources.

Place and Meybeck (2013) go into considerable detail on the rationale, principles, and measures for sustainable agricultural intensification. In this paper we highlight two aspects that are particularly important as a response to climate change: increasing resilience and diversification of agricultural systems.

\section{Increasing Resilience of Agricultural Production Systems}

The overall efficiency and resilience of crop and livestock production systems in the face of climate change can be enhanced through improving various components (FAO 2010):

- Appropriate soil and nutrient management, through composting manure and crop residues, more precise matching of nutrients with plant needs, controlled-release and deep-placement technologies, and using legumes for natural nitrogen fixation, can increase yields and resilience of crops, while reducing the need for often costly and inaccessible synthetic fertilizers (with the co-benefit of reducing the GHG emissions associated with their use).

- In situations with decreasing rainfall and increasing rainfall variability, there are many ways of improving water harvesting and retention (through the use of pools, dams, pits, retaining ridges, increasing soil organic matter to heighten the water retention capacity of soils) and water-use efficiency (irrigation systems).

- Climate change is already altering the distribution and intensity of weeds and animal and plant pests and diseases. There are considerable gaps in our knowledge of systems interactions in relation to weeds, pests, and diseases, and increased understanding will lead to better ways to manage them in a changing climate (Gregory et al. 2009). 
- Improving ecosystem management and biodiversity can provide several ecosystem services, leading to more resilient, productive, and sustainable systems that may also contribute to reducing GHGs. Such services include the control of pests and disease, regulation of microclimate, decomposition of wastes, regulation of nutrient cycles, and crop pollination.

- There is often considerable genetic variability in domestic crops and livestock, and characteristics such as ability to withstand temperature extremes, drought, flooding, and pests and diseases are often at least partially genetically controlled. The use of different crops and breeds and their wild relatives is fundamental in developing resilience to climate shocks and longer-term climate change.

- Efficient harvesting and early transformation of agricultural produce can reduce postharvest losses and preserve food quantity, quality, and nutritional value of the product. Food processing allows surplus to be stored and sales staggered, and can add resilience to agricultural systems by smoothing food security and income variability.

It is worth noting that the impacts of climate change may not be negative in all parts of the tropics. In some highland regions of Latin America and Africa, for example, growing seasons may expand as temperatures increase and cold temperature constraints to crop growth are relaxed (Jones and Thornton 2003). Even in places where crop suitability may decrease, changes in agricultural inputs and the way farmers use them may be able to more than offset projected yield declines through the use of some of the options outlined above (irrigation water, higher-temperature-tolerant crop varieties, and so on) as well as through planting date modifications (Crespo, Hachigonta, and Tadross 2011).

Fisheries and aquaculture provide more than 2.6 billion people with at least 20 percent of their average annual per capita protein intake. There is limited observational information on climate change impacts on all aquatic (especially marine) ecosystems. Many uncertainties remain, particularly in relation to the effects of synergistic and cumulative interactions among stressors such as rising temperatures, overfishing, and pollution, the occurrences and roles of critical thresholds, and the abilities of marine and aquatic organisms to adapt and evolve to the changes (Beare 2012). Many fishery resources are currently fully exploited or overexploited, and climate change adds an additional stress to the resources themselves and those dependent on them. In most cases, building resilience in fishery resources and their ecosystems requires allowing such systems to recover to healthier levels and states. However, overcapacity in fisheries is a problem. As for land-based systems, several options exist for increasing the climate resilience of aquaculture, notably through improving management approaches and selecting of suitable stock. Increasing feeding efficiency or switching to herbivorous or omnivorous species such as carp greatly reduces the need for fish feed inputs and achieves much lower input/output ratios than other protein sources. The integration of aquaculture within broader farming landscapes provides further opportunities: sludge produced during the treatment of aquaculture wastewater or pond sediments can be used to fertilize agricultural crops, for example. More strategic location of aquaculture infrastructure can also avoid potential climate change risks and minimize the impacts on natural systems such as wetland, mangroves, and reefs (FAO 2010). It can also provide an alternative livelihood in situations where saltwater intrusion has made rice farming unproductive, as in some parts of Vietnam, for example.

Trees occur on 46 percent of all agricultural lands and support 30 percent of all rural populations (Zomer et al. 2009). Both forests and agroforestry can contribute to increasing resilience in the face of climate change. Diverse, multifunctional landscapes that include forests are often more resilient to climate shocks and provide the rural poor with a broader set of options for securing both food and income (Sunderland 2011). Forest foods have been shown to be especially crucial in helping the rural poor cope with seasonal shortages and recurrent climate anomalies and economic downturns (Locatelli et al. 2012). Trees on farms serve a wide variety of purposes, and can help reduce the vulnerability and increase the resilience of farming systems while providing substantial mitigation benefits as well. Trees and tree products can increase farm income and help spread risk; trees and shrubs can reduce the effects of extreme weather events such as heavy rains, droughts, and windstorms. They prevent erosion, stabilize soils, raise infiltration rates, and halt land degradation. They can enrich biodiversity in the landscape and 
increase ecosystem stability. Trees can improve soil fertility and soil moisture through increasing soil organic matter, fixing nitrogen, and providing shade (FAO 2010). The several benefits of agroforestry options have been demonstrated on household food security in various situations, and evidence is growing that natural resource management through agroforestry can lead to improved social protection and resilience (Chaudhury et al. 2011).

\section{Diversification}

Agricultural diversification occurs when more species, plant varieties, or animal breeds are added to a given farm or farming community. It includes landscape diversification-different crops and cropping systems interspersed in space and time. Livelihood diversification implies that farming households are involved in more and different (nonagricultural) activities - for instance, by taking up a job in the city, setting up a shop, or starting to process farm products. Both agricultural and nonagricultural forms of diversification may be relevant for climate risk management, although the emphasis here is on agricultural diversification. Climate-related shocks, such as heat waves, frost, excessive rain or floods, or drought spells, have different and sometimes even opposite effects on different farming system components or economic activities.

Diversification can potentially reduce the impact of weather events on income, and it can also provide farmers with a broader range of options to address future change. Given the potential benefits, diversification is often recommended as a risk management strategy. Others criticize risk-mitigating diversification strategies and emphasize the importance of risk taking for agricultural development (World Bank 2008). If combined with risk-reducing measures, such as crop insurance, risk taking could lead to higher incomes and poverty reduction (FAO 2012c). On the other hand, if risk-averse diversification strongly decreases average income, it can lead to a vicious cycle of decreasing household assets, eventually leading to an exposure to more risk (Dercon 1996). Others have argued that crop diversification options for risk mitigation are limited due to the generally high and positive correlation between the yields of different crops (Barrett, Reardon, and Webb 2001). Such critiques need to be qualified according to the geographical context and the mix of diversification and other changes that are being considered. For instance, crop diversification options are found to be most beneficial in "intermediate" conditions, where growth conditions are neither so marginal that they limit diversification options nor optimal for a single high-return crop (Kandulu et al. 2012).

Diversification is an important element of climate change adaptation. However, little systematic information exists to guide farmers and farming communities on how to best manage diversification options in their specific context.

The risk mitigation effects of diversification can occur at multiple scales. At the plot level, intercropping varieties with different phenological traits, such as variation in time to maturity, spreads the risk of drought spells (Cavatassi et al. 2010). Ethiopian farmers growing traditional barley varieties have been found to decrease overall yield variance as well as the odds of crop failure (Di Falco and Chavas 2006). At the farm level, many households favor mixed livestock-crop systems when weather risks increase, such as in SSA (Seo 2012; Rufino et al. 2013), as livestock can be used as an asset to smooth income fluctuations (Fafchamps, Udry, and Czukas 1998; Miura, Kanno, and Sakurai 2012). Furthermore, diversified farms can play an important role in maintaining and increasing ecosystem service provision (Ricketts 2001). Maintaining a high response diversity can facilitate postdisturbance recovery (Laliberté et al. 2010) and thus compensate for the negative effects of climate change and increase overall resilience (Kremen and Miles 2012). Better ways are needed to assess the complicated linkages between (and respective costs associated with) diversification at different scales and other measures that contribute to vulnerability reduction, including agricultural insurance, weather information provision, and social protection measures. 


\section{Risk Management}

Climate change is expected to alter the productivity of the natural resource base, disproportionately affecting consumption, production, and asset accumulation of the rural poor (Hertel and Rosch 2010). Farm household decisions will typically be influenced by perceptions of risk and climate variability, household assets and the natural resource base, and the policy environment. In this respect, climate change may be regarded both as destroying information (Quiggin and Horowitz 2003) and running down assets if extreme events become more frequent. Information is particularly relevant because as climate signals become noisier, farmers' capacity to forecast the climate for planting decisions will be affected, as will their ability to evaluate the risk of extreme events. At the same time, the level of household assets, being affected by climate change, has an impact on how farm households make decisions to minimize climate risks (Lybbert et al. 2004; Ziervogel, Bharwani, and Downing 2006).

Managing risk and uncertainty has always been a priority for farmers, who are exposed to multiple forms of risk ranging from weather variability to pests and disease to price volatility. Climate change can be a risk multiplier affecting the probability and severity of such events in ways that are difficult for individual farmers to incorporate into their decisionmaking. This is particularly challenging for the 40 percent of the rural population in developing countries who are food insecure, and who also typically have the least assets and limited access to information. In this context, institutional interventions can either support farmers' own strategies at the local level or improve the wider governance of food systems to dampen the negative effects of climatic shocks on food security. Halstead and O'Shea (1989) distinguish five mechanisms for risk transfer:

- mobility - distribution of risk across space;

- storage - distribution of risk across time;

- diversification ${ }^{2}$ - distribution of risk across asset classes;

- communal pooling - distribution of risk across households; and

- market exchange - purchase and sale of risk via contracts (which can substitute for any of the above).

For each of these, there are multiple corresponding adaptation strategies and associated institutions (Table $3.1)$.

${ }^{2}$ Note that in the subsection, "Diversification," we take a broader view of diversification (in that it can have other benefits that are not primarily related to the transfer of risk). 
Table 3.1 Examples of adaptation strategies and institutions for risk transfer under climate change

\begin{tabular}{|c|c|c|c|}
\hline $\begin{array}{l}\text { Risk transfer } \\
\text { category }\end{array}$ & Adaptation strategies & $\begin{array}{l}\text { Institution-building } \\
\text { opportunities at the } \\
\text { local level }\end{array}$ & $\begin{array}{l}\text { Institution-building } \\
\text { opportunities at } \\
\text { higher levels }\end{array}$ \\
\hline Mobility & $\begin{array}{l}\text { - Agro-pastoral, wage labor, } \\
\text { or involuntary migration } \\
\text { - Distribution and trade of } \\
\text { agricultural produce and } \\
\text { inputs }\end{array}$ & $\begin{array}{l}\text { - Conflict management.- } \\
\text { for example, croppers vs. } \\
\text { pastoralists } \\
\text { - Functioning of local } \\
\text { informal markets } \\
\text { - Support to local exit } \\
\text { strategies }\end{array}$ & $\begin{array}{l}\text { - Residence and border } \\
\text { controls } \\
\text { - Safe and fair transfers of } \\
\text { remittances } \\
\text { - International trade controls } \\
\text { and tariffs }\end{array}$ \\
\hline Storage & $\begin{array}{l}\text { - Water storage } \\
\text { - Food storage } \\
\text { - Natural capital including } \\
\text { livestock and trees } \\
\text { - Pest control }\end{array}$ & $\begin{array}{l}\text { - Participatory action } \\
\text { research } \\
\text { - Local tenure and } \\
\text { entitlements } \\
\text { - Access to information }\end{array}$ & $\begin{array}{l}\text { - Incentives for affordable } \\
\text { private-sector innovation } \\
\text { - Knowledge systems for } \\
\text { pests and diseases } \\
\text { - Food safety interventions }\end{array}$ \\
\hline Diversification & $\begin{array}{l}\text { - Diversification of agricultural } \\
\text { assets, including crop and } \\
\text { livestock varieties, } \\
\text { production technologies } \\
\text { - Occupational diversification } \\
\text { and skills training } \\
\text { - Dietary and other } \\
\text { consumption choices }\end{array}$ & $\begin{array}{l}\text { - Farmer field schools and } \\
\text { other locally led } \\
\text { innovation systems } \\
\text { - Microfinance } \\
\text { - Local business } \\
\text { development } \\
\text { - Household food } \\
\text { management } \\
\text { - Local future climate } \\
\text { scenarios exercises }\end{array}$ & $\begin{array}{l}\text { - Public and private } \\
\text { extension services } \\
\text { - Accessible banking and } \\
\text { loan schemes } \\
\text { - Skills retraining linked to } \\
\text { job creation } \\
\text { - Consumer food knowledge } \\
\text { and preferences }\end{array}$ \\
\hline Communal pooling & $\begin{array}{l}\text { - Infrastructure development } \\
\text { - Community forestry } \\
\text { - Disaster preparation } \\
\text { - Labor pooling } \\
\text { - Knowledge management } \\
\text { - Redistribution among kin or } \\
\text { across society }\end{array}$ & $\begin{array}{l}\text { - Producer groups and } \\
\text { collective action } \\
\text { - Benefit-sharing } \\
\text { arrangements } \\
\text { - Capacity building in } \\
\text { climate knowledge } \\
\text { - Local accountability and } \\
\text { anticorruption measures } \\
\text { - Gender relations }\end{array}$ & $\begin{array}{l}\text { - Land and resource tenure } \\
\text { policy } \\
\text { - Cooperative and producer } \\
\text { association law } \\
\text { - Tax-funded social welfare } \\
\text { schemes and safety nets } \\
\text { - Investment in research } \\
\text { and social learning }\end{array}$ \\
\hline Market exchange & $\begin{array}{l}\text { - Improved market access } \\
\text { - Wage labor, food-for-work } \\
\text { - Insurance schemes } \\
\text { - Credit to support } \\
\text { investments, diversification } \\
\text { etc. }\end{array}$ & $\begin{array}{l}\text { - Market information } \\
\text { networks } \\
\text { - Equity of access to } \\
\text { government schemes } \\
\text { - Credit linked to adaptation } \\
\text { responses }\end{array}$ & $\begin{array}{l}\text { - Private-sector } \\
\text { procurement policy } \\
\text { - Labor standards } \\
\text { - Subsidized index-based } \\
\text { insurance } \\
\text { - Credit package design to } \\
\text { support adaptation }\end{array}$ \\
\hline
\end{tabular}

Source: Adapted and expanded from Agrawal and Perrin (2008).

Whereas some of the recommended avenues for institution building are specific to climate risks, many are generic to sustainable development, and need to build on existing development institutions such as those created in the context of community-based adaptation and disaster risk reduction. Access to credit is one such example, which has been found to facilitate diversification and other forms of adaptation for managing climate risks, but which has also played a prominent role in agricultural development and poverty reduction strategies (McCarthy et. al. 2011; Cavatassi et. al. 2010). 


\section{THE ROLES OF CGIAR AND FAO IN SUPPORTING NEEDED TRANSITIONS}

\section{Introduction}

Sections 2 and 3 highlighted the most important ways climate change may affect agricultural livelihoods in the near future and identified major categories of actions that can incorporate climate change responses into agricultural development strategies. In this section, we examine which steps might support or enable transitions that include such actions, looking at, in particular, the roles of CGIAR and FAO in this regard. Two general considerations can help frame more specific action: (1) it is important to explicitly embed adaptation and mitigation capacity into agricultural growth strategies to support food security; and (2) given the variation in the rate and nature of projected impacts, as well as differences in socioeconomic and agroecological conditions and political choices, context-specific responses will be essential — no one technology or change in agricultural systems will be the universal solution.

In recent years, both FAO and CGIAR have instituted programs that respond to each of these challenges. CGIAR has established the Research Program on Climate Change, Agriculture, and Food Security (CCAFS), a 10-year research initiative that responds to the threats to agriculture and food security in a changing climate, exploring new ways of helping vulnerable rural communities adjust to global changes in climate. In 2010 at the Hague Conference on Agriculture, Food Security, and Climate Change, FAO presented the concept of climate-smart agriculture (CSA), which is composed of three main pillars: (1) sustainably increasing agricultural productivity and incomes; (2) adapting to and building resilience to climate change; and (3) reducing or removing GHG emissions, where possible. CSA is an approach to developing the technical, policy, and investment conditions to achieve sustainable agricultural development for food security under climate change. A CSA partnership was launched shortly thereafter, including CGIAR and CCAFS, as well as several other development agencies such as the International Fund for Agricultural Development, the World Food Programme, and the World Bank ${ }^{3}$. FAO has subsequently launched a program of work on CSA that provides support to developing countries in formulating, financing, and implementing climate-smart agricultural strategies. Activities include building an evidence base on synergies and trade-offs between mitigation, adaptation, and food security as well as identifying the barriers to the adoption of climate-smart agricultural practices, supporting more coordinated and informed policymaking and risk management strategies, and supporting the development of country agricultural investment plans that incorporate adaptation and mitigation and links to climate financing. CCAFS is a partner in this work, and further expansion of collaborative work between FAO and CCAFS on CSA is planned. In the following sections, we highlight four major categories for priority actions the FAO and CGIAR can take to support stakeholders from the farm level to the national and international levels to identify and implement responses that will generate agricultural transformation to support food security under climate change: (1) promoting agricultural technologies and innovations; (2) strengthening local institutions; (3) achieving coordinated and informed policies; and (4) increasing access to financing.

\section{Promoting Agricultural Technologies and Innovations}

Through its effects on changing temperature and rainfall patterns, the incidence of extreme events, and potential shifts in pest and disease patterns, climate change is a major determinant of the effectiveness of any given agricultural technology or innovation. Box 4.1 outlines how this challenge is manifested in crop breeding in CGIAR.

\footnotetext{
${ }^{3}$ See www.climatesmartagriculture.org/en/ for additional information.
} 


\section{Box 4.1 Climate change brings challenges for crop breeding in CGIAR}

Plant breeders have been responding to climate-related stresses for a long time, but climate change is adding urgency to new breeding activities and the use of new technologies directly linked to factors such as increased drought, more extreme temperatures, more widespread flooding, higher levels of salinity, and shifting patterns of pest and disease occurrence, all of which are associated with climate change. The ways in which breeding is carried out are changing. Many CGIAR centers have adopted new collaborative forms of germplasm development and diffusion involving various kinds of partners. An example is CIMMYT's MasAgro project, a partnership of more than 50 national and international organizations dedicated to improving sustainable agriculture. Projects like MasAgro have been influenced by the shift in international development culture toward achieving impact and thus the need to provide farmers with tangible, measurable ways to improve their production systems. Others are using participatory approaches to crop improvement, such as the International Center for Agricultural Research in the Dry Areas, through participatory variety selection in collaboration with national agricultural research organizations (NAROs) and nongovernmental organizations (NGOs). Some of this work focuses on adaptation to climate change. Centers are also working on parental lines to be used by private companies for the development of hybrid varieties. Recent partnerships with the private sector are leading to uptake and diffusion of improved technologies that were not otherwise possible. Still other centers, in collaboration with NAROs, are collaborating directly with farmers' organizations and NGOs to select the most useful varieties and then bulk up quality seed and distribute it to farmers. The International Crops Research Institute for the Semi-Arid Tropics, for example, is making small seed packets available commercially to farmers.

Centers have also been looking closely at their breeding objectives. With climate change, average temperature effects are important, but there are other temperature effects too. Increased night-time temperatures have negative effects on rice yields, for example, and increases in maximum temperatures can lead to severe yield reductions and reproductive failure in many crops. There may be genetic differences in plant response to such changes, and those could be exploited in future breeding programs. The increases in atmospheric concentration of carbon dioxide $\left(\mathrm{CO}_{2}\right)$ that are driving climate change provide challenges as well. Increased $\mathrm{CO}_{2}$ can have a beneficial effect on many crops, although it may decrease the protein concentration in wheat grain, for instance. In beans, genetic differences in plant response to $\mathrm{CO}_{2}$ have been found, and those could be exploited through breeding. The impacts of climate change on the pests and diseases of tropical crops and livestock are not well understood, but in the future there could be substantial gains from breeding programs that exploit the natural resistance found in some plants and animals.

Sources: Vernooy (2012) and Thornton and Cramer (2012).

Explicitly incorporating the effects of climate change, and the need to adapt as well as the potential to mitigate, into agricultural strategies has important implications for assessing technologies for broad dissemination. In the CSA approach, adaptation and food security are considered the primary objectives for agricultural intensification, with mitigation as a co-benefit. Both CGIAR and FAO have done considerable work on assessing where trade-offs arise between those objectives for a given location and strategy, as well as where synergies can be achieved. Indicators and analysis are needed for such assessments. For example, to identify adaptation benefits from any specific agricultural development activity, we need to have an idea about how climate change is projected to affect that location and agricultural system, as well as about the effectiveness of strategies for reducing vulnerability and increasing adaptation to such changes. For mitigation we need to understand the increase in emissions that could be expected under a conventional agricultural growth strategy, as well as the degree to which such business-as-usual baseline emissions could be reduced under alternative agricultural growth strategies. 


\section{Promoting Capacity to Innovate}

Of course, it is not just identifying the right technologies or practices that will result in successful change at the field level: the engine that will drive sustained adaptation and transformation of agricultural systems is innovation of all forms - social, institutional, and technological. Innovation is the process by which social actors create value from knowledge. It emerges as the cumulative result of millions of interactive, experiential learning cycles involving the social actors-laborers, farmers, entrepreneurs, policymakers, and so on. From this point of view, the key question becomes "How can agricultural research for development (Ag R4D) better foster rural innovation so as to build adaptive capacity for food security and well-being under climate change?"

Complexity science points to three levers for fostering innovation: increasing the pool of new ideas and technology that feed into learning cycles, changing how people interact while innovating and making sense of the results, and changing the ways they measure and select what works and what does not (Axelrod and Cohen 2000). Behind this is the notion that innovation is an evolutionary-like process driven by "learning selection" analogous to "natural selection" (Douthwaite 2002).

Ag R4D has largely focused on the first lever, probably because arguably its greatest success came through the contribution high-yielding crop varieties made to the Green Revolution. This has reinforced a still-dominant pipeline view of the role of Ag R4D in which the researchers' primary job is to deliver technological fixes rather than to support local capacity to innovate.

If Ag R4D is to better support adaptive capacity, it needs to put greater emphasis on the second and third levers by developing approaches that change the ways in which people interact while innovating and by developing methods that help people make better and faster decisions about how technology and institutions are working. This implies a greater emphasis on networking - both its practice and the theory behind it.

By emphasizing learning and networks in the innovation process we aim to foster, we will simultaneously support building "latent social capacities" (Pelling and High 2005), which are useful for long-term adaptive capacity. Through this lens different types of social network structures and functions that support adaptive capacity become visible so that both formal and informal networks are of particular importance in climate change adaptation (Pelling et al. 2008). Gender plays an important role in social networks and thus is a fundamental consideration in their use for promoting innovation and adaptive capacity (Sarapura 2009; Malhotra et al. 2009).

We already use a range of practices and interventions in R4D to alter network structure and the quality of the links within, including setting up different types of formal networks or innovation platforms and various types of collaborative and participatory research in which different social agents engage in joint inquiry to solve problems, building relationships and capacity in the process. Box 4.2 describes one example.

\section{Box 4.2 Building youth networks to support innovation}

An example of an innovative model for building new networks to support technology transfers comes from an FAO-supported project aimed at increasing youth employment implemented in 2011 in Malawi and Tanzania. The project involves the countries' public and private sectors in training youths in agricultural-sector-related activities - including climate-smart agriculture practices. Assessments of the program indicate that when back in the home districts, youths that had participated in the program were actively involved in mobilizing and sensitizing their peers to innovations learned through the program. The spillover effect initiated by the youth themselves when returning to their villages is as important as the initial effects of the training. The private sector gains new, young, and skilled members while the public sector decreases the number of unemployed rural youth. The model offers facilitated access to markets for young people's products through the producer organization networks while the youth gain a fair, negotiated price for their produce and a voice in local associations.

Source: FAO (2012e). 


\section{Strengthening Local Institutions}

Local institutions, both formal and informal, play a key role in facilitating and encouraging agricultural producers to make changes in production systems, manage natural resources, and manage their overall livelihoods to achieve food security under climate change. Local institutions are a conduit for transferring information on climate change effects on weather patterns relevant for agricultural production decisions, new technologies and practices, and new market opportunities. Implicitly or explicitly, local institutions can support the capacity of local populations to identify and manage risks. Such institutions are also central in implementing (and in many cases devising) rules by which productive assets, such as land, water, and trees, can be accessed and collective action can be undertaken. Given their importance in regulating access to productive assets, the way in which gender relations are incorporated into such formal and informal institutions is a crucial determinant of women's access to such assets. As such, incorporating the gender dimension into assessments and strategies for strengthening local institutions is essential. There is a vast literature on the role of local institutions in supporting sustainable agricultural intensification and development (McCarthy, Lipper, and Branca [2011] provide a recent review), but here we focus on three key functions under climate change: information generation and dissemination to agricultural producers, risk management, and collective action. Building and strengthening networks to support adaptive capacity as described in the preceding section is an important way of improving the performance of local institutions. Some examples of how innovative approaches mobilize both formal and informal institutions and networks to strengthen local institutional capacity for information dissemination, risk management, and collective action follow.

\section{Information Generation and Dissemination}

Much effort has been invested in helping farmers make more effective climate-sensitive decisions (for example, planting times, livestock shelter) via improved access to timely, meaningful, and trustworthy climate information and knowledge. This work links a technical component-development of agroclimatic tools (Hansen and Coffey 2011) - with institution building to improve channels both for uptake of information and for demand for that information, allied with new information technology (Box 4.3). Evaluations in Africa show that investing in institutions for sharing of seasonal forecasts (one key area of climate information) can increase farmers' capacity to reduce their exposure to risks (Hansen et al. 2011). Likewise, for disaster relief agencies, overcoming institutional barriers to the use of seasonal forecasts has proven critical to saving lives during climate crises (Tall et al. 2012). For farmers and higher-level agencies alike, relevant institutions include channels for two-way communication across barriers of language and scientific understanding, systematic capacity building of both users and providers of information, and trust building among partners. Information transfers may occur between a number of sources and recipients, including government extension programs and nongovernmental organizations or donor programs. Box 4.4 describes an innovative way of linking farmers to extension information.

\section{Box 4.3 New ways of getting information to (and from) farmers}

The continuing rapid pace of change of technology is opening up new opportunities. For example, a new global cropland data layer was recently developed by the International Institute for Applied Systems Analysis in Austria with many partners, including FAO and CGIAR, and it has been calibrated using crowd sourcing. More calibration data are being collected using the Geo-Wiki land cover validation tool (geo-wiki.org), and it is being developed into a multi-mass-player game with support from CGIAR partners. Other examples are using mobile phone technology to collect household survey and farming systems data using crowd sourcing, and using mobile phone transmission towers to collect rainfall data and as a basis for providing flash flood warnings. Recent advances in high-resolution satellite imagery and making it more readily accessible are opening up other opportunities in monitoring land-use change and weather forecasting, for example.

Source: van Etten (2011). 


\section{Box 4.4 Audio conferring for extension service delivery in Ghana}

Many young Ghanaian farmers are losing confidence in the quality of extension services because extensionists do not come with demand-driven extension messages via innovative methodologies. Farmers are usually not involved in the development of the extension content and therefore find the extension services not adequately tailored to address their farming challenges in order to enable them to take up agriculture as a business and a sustainable livelihood. The Savannah Young Farmers Network (SYFN), a youth-led nongovernmental organization in Ghana, is running the Audio Conferencing for Extension project in the north of Ghana, offering innovative extension services. SYFN organizes the audio conferences for extension service twice a week with farmer groups consisting of a minimum of 10 and a maximum of 15 farmers. During the audio conferences, farmers are put in touch with agricultural officers from SYFN and other agricultural extension experts, agronomists, information and communications technology professionals, and agricultural researchers. A cell phone with an audio conferencing system is used and attached to a portable loudspeaker to enable all farmers present at the conference to interact with the advisers. Community agricultural information officers are present with the farmers to ensure that the capacity-building sessions are well planned and moderated and that the desired impact is achieved.

Source: SAVANET (2013).

Providing appropriate information, such as improved forecasts and better ways to communicate them, and designing appropriate safety nets that enable farmers to make informed decisions are particularly important under climate change. Several areas warrant particular attention:

- Information on climate change and possible responses can be improved and made more relevant to farmers and communities. This is linked to a rich body of literature that indicates that risk perceptions and behavioral biases, often due to limited information or poor communication, affect the response to increased climate variability, indicating the need for participatory approaches to appropriate policy formulation (Patt and Schröter 2008; Marx et al. 2007). Areas where improved information and communications would be beneficial include local forecasts and communication in a way that is relevant to farmers, availability of technological options that are appropriate under evolving climatic conditions, and how to overcome barriers to adoption.

- Even with the best available information, climate change introduces additional uncertainty, both in terms of probabilities and extent of exposure to impacts and farmers' behavioral response, which requires new approaches to identify appropriate courses of action (Clarke 2008; Hallegatte et al. 2012; Heltberg, Siegel, and Jorgensen 2009; Dalton and Muhammad 2011; Brunette et al. 2012; Antón et al. 2012).

- Because women experience many obstacles to accessing and using information, it is important to explicitly consider gender in measures to improve the access of rural populations to climate information. Lower levels of education, literacy, and math skills among women reduce their capacity to access and process information delivered through modern sources such as information and communications technology. Additionally, women are more likely to speak local dialects than national languages, representing another barrier. Combining traditional means of communication and information sharing with modern ones to create "hybridized" communication strategies is one way to overcome this challenge (McOmber et al. 2013). Examples include the use of intermediaries to assist women in accessing information and communications technology, targeting extension programs to overcome these gaps, and targeted use of rural radio programs.

Information also interacts with the role of assets (physical, human, and social) in choosing appropriate courses of action and the ability to act upon the information received. This point is also linked 
to the interaction of the damage incurred by farm households (especially subsistence producers) and potential opportunities for farm households through markets (Hertel and Rosch 2010; Ziervogel, Bharwani, and Downing 2006). A better understanding of the role of different types of assets in building resilience and diversifying sources of income in the face of climate change and other shocks is critical for vulnerable households and should be part of a broader strategy for managing risk. In such a broader context, information also matters for how policy design, such as safety nets, affects farmers' management decisions, incentives to adapt, and resilience, addressed in the context of assets, perceptions, and communication.

\section{Design Elements in Managing Risk}

Several aspects need to be taken into consideration when trying to address the increased risk and uncertainty created by climate change. These are the extent to which

- it is possible to know how climate change affects the probability distribution of events at a spatial scale that is relevant to farmers;

- all actors (farmers, policymakers, extension agents) are adequately informed of, and correctly perceive, how climate change affects the probability distribution of events;

- information is available on the technology and policy options to address the impacts; and

- barriers to adoption (financial, institutional, technical) may hinder effective risk management under climate change.

A traditional risk management approach typically assumes that probabilities are known by all actors. However, climate change may disrupt traditional risk management because historical experience may no longer apply and knowledge of probabilities may be challenging to update, requiring a better understanding of the local impacts of climate change and how to communicate such knowledge and possible responses. Given limited resources to finance adaptation actions, a top priority is that such support be appropriately targeted to those whose livelihoods are more vulnerable. However, adaptation responses may differ even within such a targeted group, depending on assets, access to information, perceived risk, and social relations in the community (Pelling and High 2005; Patt and Schröter 2008; Grothmann and Patt 2005).

FAO and CGIAR are working in a variety of ways on different approaches to helping smallholders manage risk. As noted earlier, the provision of timely weather information can help rural communities manage the risks associated with high rainfall variability. Some issues still need to be addressed in relation to the effectiveness of climate forecasts for crop and livestock management, particularly regarding effective mechanisms for delivery and utilization of such information, but progress is being made on this front via several case studies undertaken by CGIAR and partners in countries in SSA (Hansen et al. 2011). Another example is livestock insurance schemes that are weather indexed (that is, policyholders are paid in response to trigger events such as abnormal rainfall or high local animal mortality rates). CGIAR is involved in index-based livestock insurance pilots based on satellite imagery in some of the drought-prone areas of East Africa, and these are highlighting the potential for publicprivate partnerships in situations where the incentives and risks involved do not make it feasible for the private sector alone (Chantarat et al. 2012). FAO is exploring the potential agricultural risk mitigation effects of social safety net programs such as cash transfers to support education and health outcomes. Given the rapid increase in social safety net programs throughout developing countries, their large reach across agricultural populations, and their overall effect of reducing risks of income losses, such programs could potentially have a significant effect on risk management in agricultural production systems. FAO is exploring the potential effect of such programs, as well as possible design features that may enhance their agricultural risk management properties, through assessements of existing programs. 


\section{Fostering Collective Action}

In many farming systems, a number of activities are more effective when undertaken by groups rather than by individuals alone, such as addressing market failures, providing local public goods, and managing communal resources. Many of the biophysical improvements to increase resilience and mitigation in smallholder agricultural production systems require action and coordination among many stakeholders in the rural landscape. Restoration of degraded areas to improve soil quality, improved management of communal water and pasture resources, and informal seed systems to facilitate the exchange of plant genetic resources are all examples of collective resource management activities that are likely to become more important under climate change. In many cases, local institutions exist to govern collective action and access to collective natural resources, but they are often coming under increased pressure due to population growth, conflicts, changes in market patterns, and state intervention (Meinzen-Dick et al. 2002; McCarthy et al. 2000; FAO 2012a).

Climate change gives rise to new and increased demands for collective action. For example, climate change is likely to increase the benefits to flexible access to resources, which has important implications for the design of land tenure security programs. In many cases, rights to land are unclear, overlapping, and not formalized. Increasing security of rights to resource use does not necessarily mean formalization of such rights, but rather a system for identifying, coordinating, and recognizing informal rights. Ambiguous, complex, and overlapping rights to resources often serve as an insurance mechanism, which is especially important where other safety nets are not available, and this is likely to become even more important with increased weather variability (Goodhue and McCarthy 2009; Chimhowu and Woodhouse 2004). Increasing tenure security, then, requires a sound understanding of current claimants' circumstances. A process of moving through different stages toward formalization - from legally unacknowledged, customary tenure through to state-backed freehold title - is often the best way to maintain the benefits of customary tenure and incorporate the benefits to individualized tenure as these become relatively more important.

Meinzen-Dick, Markelova, and Moore (2010) characterize possible actions smallholder agricultural producers could take in response to climate change by their temporal and spatial scale, and find that they fall into a wide range between the community and individual levels for implementation, implying the need for collective action. They include not only changes in managing agricultural production systems and natural resources, but also changes in accessing markets and emerging sources of climate finance.

\section{Achieving Coordinated and Informed Policies}

\section{Policymaking for Sustainable Agricultural Development under Climate Change}

The preceding analysis indicates that policies for sustainable agricultural intensification and development remain very relevant in the context of climate change, with perhaps some shifts in emphasis. Clearly policies to support resource-use efficiency are essential, and in many cases that involves removal of existing policies that provide perverse incentives for inefficient use. Reforming poorly structured input subsidy programs that encourage poorly targeted use of fertilizers, pesticides, and water is thus a priority. Integrating the projected impacts of climate change on water availability and demand is essential, especially in the context of irrigation, where large capital investments are required. Policymakers must attend to not only changing water supply and demand conditions, but also the need for irrigation systems that are managed to promote efficient water use. Agricultural pricing policies have a major impact on the incentives to diversify agricultural production systems, and here, again, the policy challenge is often reforming existing policies that promote specialization into one major crop. Providing necessary evidence and analysis to support agricultural policy reforms to promote greater efficiency is an area where both FAO and CGIAR engage extensively. For example, the IFPRI IMPACT model (International Model for Policy Analysis of Agricultural Commodities and Trade) is an important tool for analyzing policy reforms 
under climate change and has been used extensively to look at issues of irrigation development, agricultural investment patterns, and agricultural pricing patterns.

This paper has highlighted the importance of risk management for sustainable agricultural growth, as well as the major effects climate change has on it. Thus policymaking to enable more effective and coordinated risk management is essential. Broad approaches that consider various sources of risk and their changing profiles, as well as the relative benefits and costs of risk management approachesincluding insurance, diversification, safety nets, and disaster risk management - are needed to support effective policymaking for risk management under climate change. Climate change also affects agricultural research and extension policies, requiring greater emphasis on building adaptive capacity and innovation to respond to rapid and uncertain change, as well as integration of climate change effects on rainfall, temperature, and pest and disease patterns on research agendas. FAO and CGIAR are already active in both of those areas; however, this work needs to be broadened and deepened to realize effective risk management and agricultural research and development policies under climate change.

\section{Promoting Policy Coordination}

Given the cross-cutting nature of the response needed to achieve rapid transformation of developingcountry agriculture, institutional and policy innovations that favor greater integration and coordination will be essential. Key requirements include (1) the holistic approach advocated by FAO's CSA initiative, CCAFS, and the Committee on World Food Security (CFS) in addressing food security, agriculture, and climate change; (2) the involvement of multiple stakeholders, sectors, policy areas, time horizons, and levels of governance; (3) the need for dealing with complexities, uncertainties, and volatilities, and (4) coping with the current fragmentation of the existing institutional architecture at national and international levels.

The consequences of unaligned policies can be serious. Increasing demand for food, fuel, and carbon storage in biomass and soils cuts across multiple policies - bioenergy, climate change, food security, agriculture, and forest - and can result in fragmented approaches to land use.

Greater interaction, consultation, and dialogue among ministries of agriculture, environment, and finance, as well as other key stakeholders are needed to enable more coherent policies, planning, and investment. FAO and CGIAR can play an important role in facilitating such interactions, through capacity building as well as convening technical and policy consultations.

\section{Linking Food Security and Climate Change at the International Policy Level}

Explicit consideration of agriculture within the UNFCCC negotiations, shaped by the Bali Action Plan, began only in 2009. It has remained marginal to the negotiations as a whole and, in the context of climate change and land use, has been overshadowed by REDD+ (reducing emissions from deforestation and forest degradation plus conservation and sustainable management of forests and the enhancement of forest carbon stocks). Some developed and developing countries have called for a program of work on agriculture under the Subsidiary Body for Scientific and Technological Advice, but so far others have not agreed to this proposal. Lack of agreement has resulted in little progress in making agriculture a standalone issue, wherein adequate attention is given to its specificities within the negotiations. There are fears that this may lead to policies that ignore the important linkages between food security, agriculture, and climate change, with perverse effects for one or all. There are also fears that this may directly affect potential access to climate financing by some of the most climate and socioeconomically vulnerable countries with agriculture-based economies. The climate change negotiations have undoubtedly been a catalyst for action on agriculture and climate change at the country level. At that level, there is currently keen interest and a broad range of initiatives. Some believe a lack of explicit international enabling policy may adversely affect the momentum and sustainability of such efforts.

Advocacy and information provision on the specificities of the agricultural sector and its importance to food security are needed to support international policy dialogues and negotiations to reach an agreement that allocates responsibilities, commitments, and financing to achieve a global response to 
mitigating and adapting to climate change. FAO and CGIAR have been active in the UNFCCC discussions in providing information about the magnitude and nature of policy, technical, and financing needs to support adaptation in the agricultural sectors of developing countries, as well as on the potential to design mitigation-financing mechanisms to capture synergies with food security and adaptation objectives.

The CFS commissioned its High Level Panel of Experts (HLPE) to prepare a report on food security and climate change for its consideration in 2012. The report was presented and discussed at a policy roundtable at the 39th CFS session held at FAO in October 2012. In its final report on the session CFS referred to this policy roundtable and outlined relevant action, which it invited key stakeholders to undertake in order to address the effects of climate change on food security. Both CCAFS and FAO were involved in the policy roundtable preparations and are interested in supporting country action to achieve food security under climate change.

\section{Linking Policy and Research under Uncertain Futures}

As we outlined earlier, policymakers in developing countries concerned with agricultural growth and development for food security under climate change are operating under increasing uncertainty and yet need to be cognizant of trade-offs and synergies between multiple objectives of strategies and implications for risk management-considering short-run exigencies as well as long-run implications. Clearly this is a huge challenge, requiring accessible and reliable information, analysis, and evidence. This is where improving links between researchers and policymakers becomes essential.

Planning in a policy context is often incremental and relatively short term, oriented toward a single, normative vision, and based on notions of acting on a high-likelihood forecasted future, or a combination of these elements. In the context of future uncertainty generated by interacting biophysical and socioeconomic changes across multiple system levels concerning issues of food security and climate adaptation, this type of policymaking is limited and potentially dangerous. In such issues related to complex systems change, there is a need for policy to engage future uncertainty together with research to avoid planning blindly (Wilkinson and Eidinow 2008). This is without even considering political realities and the changing strategic positions of actors. Scenarios that explore multiple plausible futures together with key stakeholders across multiple sectors have the potential of informing such a science-policy interface and allowing diverse actors to share and combine perspectives (Kok, Rothman, and Patel 2006). Scenarios are effectively alternative narratives of the future, developed in words, numbers, images, or other formats, that are based around a complex systems perspective and therefore do not seek prediction but rather a scoping of plausible future contexts and the consequences they might have for decisionmakers (van Notten et al. 2003).

CCAFS, for example, is engaging governments, the private sector, researchers, civil society, and the media in multistakeholder scenario processes at the subcontinental level in East and West Africa and South Asia. Together, these stakeholders explore key socioeconomic uncertainties for future food security, environments, and livelihoods. Multiple socioeconomic scenarios are developed by stakeholders and then quantified using agricultural economic models: IMPACT (Rosegrant, Agcaoili-Sombilla, and Perez 1995) and GLOBIOM (Havlík et al. 2011). Socioeconomic scenarios are combined directly with climate scenarios to explore how these human and biophysical future stressors interact to affect future food security, environments, and livelihoods.

Through the scenario processes in multiple subcontinental regions, CCAFS seeks to expressly engage in decisionmaking processes by asking decisionmakers to "back-cast," or plan backwards, from desired policy objectives, in the different contexts offered by multiple scenarios, each of which offers its unique challenges and opportunities for policy options and strategies (Kok et al. 2011). Through a continual engagement process (Reid et al. 2009), the implementation of the outcomes of such processes is then facilitated by CCAFS partners experienced in intersectoral work. An FAO-supported CSA project is now engaging with CCAFS to develop similar processes for Malawi and Zambia in the context of climate adaptation. Furthermore, FAO's Agricultural Development Economics Division (ESA) and CCAFS aim 
to work together on a regional process for Southeast Asia to develop and use scenarios with actors across multiple sectors.

The direct combination of stakeholder perspectives with quantitative modeling through socioeconomic and climate scenarios provides a linked science-policy interface, especially when there is ample time for feedback and iteration between the two sources of knowledge. The use of the qualitativequantitative scenarios as context for policy development further integrates the two domains. However, researchers involved in such science-policy interfaces have to be careful not to be naïve about the realities of policy and avoid assuming that policy actors are not strategic, are open about their motivations, have no self-centered interests, and do not consider the behavior of others in the policy arena (Dryzek 2009). These realities of policy engagement offer challenges for researchers. A preliminary insight emerging from CCAFS work is that if socioeconomic scenarios feature the wicked problems of policy reality such as a lack of policy implementation, corrupt practices, and so forth, they can form the basis for more grounded strategizing with policy actors, leading to strategy development that participants considered highly engaging, challenging, and plausible.

\section{Increasing Access to Financing}

Recent reports on agricultural and climate finance give some indication of a financing gap to support agricultural transitions for food security under climate change. The FAO's State of Food and Agriculture report for 2012 on investment in agriculture found that two important measures of agricultural investment - expenditure per worker, and share of agricultural expenditure related to importance of the sector in GDP - were low and declining in the two regions of the world where agricultural transition for food security is most important, South Asia and SSA. The report also indicates that poor targeting of public-sector investments to activities that provide private benefits rather than the public goods needed to underpin sustainable development is a widespread problem, particularly in areas with high levels of food insecurity and high dependence on agriculture. Redistributing investments in agriculture to those areas that give the highest returns to poverty reduction and food security is needed. For example, increasing shares of expenditure on agricultural research and development, roads, and education and decreasing subsidies for private goods such as fertilizer inputs is needed. The HLPE (2012) concludes that realizing the potential of smallholder agriculture to contribute to food security will require investments in collective action, private initiatives, and public goods. It calls for the development of national smallholder agricultural investment strategies to address existing gaps in financing. It also notes the potentially important role of the private sector in meeting this challenge, through public-private partnerships.

Buchner et al. (2012) estimated a total of US\$345 to $\$ 385$ billion in climate financing flows for 2010-2011, which is overwhelmingly directed to mitigation activities primarily in the energy and transport sectors. Some 33 percent of that finance was directed to emerging economies: Brazil, China, and India. The report found that the agriculture and forestry sectors were the main recipients of climateresilient finance in the period 2010-2011, receiving 27 percent (US\$4.4 billion) of the total. Multilateral development finance organizations allocated 12.7 percent of total adaptation finance to capacity building and technical assistance, including awareness-raising programs, training to address vulnerabilities, earlywarning systems, and strengthening of institutions, policies, and regulations. Dedicated climate funds, such as the Pilot Program for Climate Resilience, accounted for only 2.5 percent of total adaptation finance to the agriculture and forestry sectors.

So far, climate finance has largely bypassed the agricultural sector. Most public-sector climate finance, as well as almost all private-sector climate financing, flows into mitigation activities in the industrial and energy sectors. Although the newly established Green Climate Fund might shift the balance between mitigation and adaptation funding in the midterm, adaptation financing, with a significant part targeting agriculture activities, is still small in comparison to mitigation financing. In addition, the traditional separation of mitigation and adaptation in funding sources has hampered the ability to invest in activities that generate synergies, a key facet of CSA. 
However, there is some indication that public sources of climate finance could play an increasingly important role in meeting the CSA investment gap. A recent positive development in CSA financing is the Global Environment Facility's (GEF's) movement toward combining adaptation and mitigation activities in the draft GEF-6 climate change mitigation strategy (FAO 2012e). To successfully access and use increasing volumes of international CSA financing, developing countries will have to ensure that necessary prerequisites are in place. This requires building an evidence base to indicate potential adaptation and mitigation benefits from agriculture, as well as the institutional capacity for monitoring and verifying such benefits.

There are three important challenges to securing financing for needed agricultural investments. First, overall financing flows are inadequate to meet investment demands, implying a need for increasing flows and, perhaps even more important, improving the capacity of existing financial flows to stimulate increases from sources currently underinvesting. The most important example here is better targeting of public-sector finance to leverage and incentivize private-sector investments, particularly those from agricultural producers themselves. Second, the overwhelming allocation of climate finance to mitigation indicates the need to develop policies and financing mechanisms to increase financing for adaptation, as well as a need to identify where mitigation finance and the activities it supports are synergistic with adaptation. Third, better targeting of agricultural and climate financing to agricultural transitions that generate the highest returns to food security is needed. FAO and CGIAR have important roles to play in meeting each of these challenges, through advocacy, policy and investment support, and the development of financing mechanisms appropriate to supporting agricultural transitions.

FAO and CGIAR are engaged in building an evidence base for identifying where synergies can be obtained between mitigation and food security/adaptation in agricultural transitions. Analysis of tradeoffs and synergies between objectives are being carried out by both CCAFS and the FAO CSA project. The FAO MICCA (Mitigation of Climate Change in Agriculture) program and CCAFS have a coordinated program on agricultural mitigation for food security. Two pilot projects, a smallholder livestock system in western Kenya and conservation agriculture with trees as an alternative for slash and burn in Tanzania, act as laboratories for developing menus of climate-smart practices - building capacities to adopt them and measuring their impact on emissions and livelihoods of the farmers. The knowledge generated is used for capacity development at the national level and also fed to the UNFCCC process as technical advice. A community of practice links people all over the world, sharing experiences of good practices, solving problems, and learning through virtual learning events.

Both FAO and CGIAR provide technical support to national agricultural investment planning. The degree to which climate change adaptation and mitigation is integrated into such investment planning varies considerably, and improvements are needed in this area. FAO and the World Bank developed a method for screening agricultural investment plans to identify climate-smart agricultural investments, and one of the main outputs of the FAO CSA project is the development of country agricultural investment plans that integrate adaptation and mitigation and explicitly link to sources of climate finance. One of the main barriers to linking climate finance to agriculture is the need for measurable, reliable, and verifiable indicators of adaptation and mitigation benefits from agricultural transitions, and this is another area in which CGIAR and FAO can clearly provide support. In the following section, we examine the issue of developing indicators to measure progress on agricultural transitions to achieve food security under climate change. 


\section{MONITORING AND EVALUATION}

\section{The Importance of Monitoring Progress toward Development Outcomes in FAO and CGIAR}

Both FAO and CGIAR are undergoing reforms to improve the effectiveness of their respective work programs. A fundamental aspect of this is moving to the use of results-based frameworks that require the development of indicators for tracking progress toward stated objectives. First we provide a brief overview of recent developments in FAO and CGIAR related to the development of indicators. Then we move on to discussing suggested indicators for tracking progress in making agricultural transitions to support food security under climate change.

In 2012 FAO initiated a process to develop a new framework organized around five strategic objectives:

1. Contribute to the eradication of hunger, food insecurity, and malnutrition.

2. Increase and improve the provision of goods and services from agriculture, forestry, and fisheries in a sustainable manner.

3. Reduce rural poverty.

4. Enable more inclusive and efficient agricultural and food systems at local, national, and international levels.

5. Increase the resilience of livelihoods to threats and crises.

Climate change poses a challenge in all of these strategic objectives, and actions to help countries cope with the effects of climate change in strategies to meet these five objectives are currently being defined. Organizational outputs are aimed at achieving changes at four broad levels: agricultural producers (defined to include crops, livestock, fishery, and forestry); national policymakers and regulators; international policy/governance processes; and a broad set of stakeholders involved in efforts to change the governance, policy, institutional, and technical processes in countries related to obtaining each of the strategic objectives. The type of action FAO envisions taking to support transitions at these four levels encompasses technical support, policy assistance and guidance, capacity building, information gathering, and dissemination and analysis.

For CGIAR, a Strategy and Results Framework provides the basis for setting priorities, identifies metrics to measure success in implementation, and connects the performance of the 16 CGIAR research programs (CRPs) to a set of system-level outcomes (SLOs). The SLOs are as follows:

- Reducing rural poverty: agricultural growth through improved productivity, markets, and incomes has been shown to be a particularly effective contributor to reducing poverty especially in the initial stages of development.

- Improving food security: access to affordable food is a problem for millions of poor people in urban and rural communities, and it requires increasing the global and regional supplies of key staples and containing potential price increases and price volatility.

- Improving nutrition and health: poor populations suffer particularly from diets that are insufficient in micronutrients affecting health and development, particularly in women and children.

- Sustainable management of natural resources: agriculture demands better management of natural resources to ensure both sustainable food production and provision of ecosystem services to the poor, particularly in light of climate change.

The SLOs represent a distinctive set of interactive targets for the contributions of agricultural research to development (CGIAR 2011). They are being linked to sets of quantitative intermediate development outcomes (IDOs) developed both top-down and bottom-up for each of the CRPs and linked to CRP activities. A key part of this process is the installation of data-gathering and synthesis capacity, along with agreement on consistency regarding data and metrics by which progress toward the IDOs can 
be regularly evaluated. The setting up of this cascade of CRP activities, objectives, outcomes, IDOs, and SLOs is not yet complete, but it should be in place by the end of 2013. Having been negotiated with a wide range of stakeholders and investors, it will provide sets of quantifiable indicators by which the CRPs will be evaluated in the coming years. At the same time, a balance is likely to be needed between quantitative and qualitative indicators: it is not always possible to measure important outcomes, and research is inherently a risky business. Such considerations coupled with the need to allow for failure and for rapid response to things of the moment that suddenly arise all point to the need for learning cycles as we go about pursuing the IDOs.

\section{Developing Metrics to Monitor and Evaluate the Necessary Transitions}

A robust framework with specific indicators and metrics of whose behavior has changed and how, across food systems, is a tall order for several reasons. First, from an adaptation perspective, there are almost no universally agreed-upon indicators to measure adaptation "success" (Hedger et al. 2008) in any sector, and a recent review indicates that food system- and food security-specific adaptation measures largely do not exist (Chesterman and Ericksen 2013). Second, dealing with climate change across food systems will entail transitions and behavior change at multiple temporal, spatial, and institutional levels. Both adaptation and mitigation will require both short- and long-term decisions, catering for immediate needs as well as systemic changes (Antle and Capalbo 2010). Third, behavior change requires collective learning and action, so monitoring frameworks have to allow for learning to modify intended strategies. Fourth, the success of any intervention can be evaluated from more than one perspective; often economic tools are used, but goals such as food security and environmental security also have normative and socially defined dimensions, as well as physical. Trade-offs between these different perspectives are often unavoidable. Finally, uncertainty is an inherent feature of the future, especially for climate change. Multiple drivers, including food prices and income growth, affect adaptive capacity in food systems, and their interactions are uncertain, as are the specific impacts of climate change on precipitation, temperature, seasonal and annual variability, and extreme events. Thus we are monitoring impact under uncertainty and have low predictive capacity.

Here we set out several premises that make the monitoring and evaluation (M\&E) challenge a little more tractable. First, for both FAO and CGIAR, the desired outcomes from food systems clearly relate to food security, enhanced livelihoods, and enhanced ecosystem services. Several priorities pertaining to those outcomes can readily be identified: increased returns to smallholder agriculture, reduced vulnerability to income shocks, increased efficiency in the use of scarce resources, increased nutritional value, and reduced emissions growth rates associated with agriculture. Thus, even though there is uncertainty inherent in the future and dynamism along the transition pathways that make monitoring of behavior change challenging, the desired outcomes will not change. And for any given context, we can identify desired targets for the outcomes, such as a percentage increase in the food secure, a percentage increase in income from food systems, and target levels of soil carbon and other ecosystem services. Third, elsewhere in this paper we identified several areas of intervention and elaborated the desired behavior change for each. As many of the interventions have been tried before in multiple contexts, an evidence base can be compiled.

We advocate the use of a food systems framework such as that outlined by Ericksen (2008) and Ericksen et al. (2010) to develop metrics and indicators for M\&E of the adaptation interventions described for food systems. This allows for assessment of the impact of an intervention across food systems, the interactions between interventions, and the trade-offs among outcomes (Warner et al. 2012). It also allows for Antle and Capalbo's (2010) approach to M\&E under uncertainty, in which the desirable objectives of food systems are evaluated under a range of conditions for agricultural growth and food security, allowing for different strategies adapted to the changing and uncertain conditions. A more resilient food system, they argue, is one that ensures the desired objectives under more than one future scenario. There are various examples of scenario-based approaches; CCAFS, for instance, is using participatory scenarios as a tool to stimulate regional and national action on adaptation and mitigation in 
the face of perceived climate change, under varying economic, political, and social conditions (Vervoort et al. 2014).

Ex ante assessment of adaptation and mitigation investments and interventions is one first step, followed by continued monitoring as the change process unfolds. This will require the sharing of data and model results from both site-specific and more general regional assessments. We are limited by the fact that few analyses to date combine the economic, physical, and social impacts (Antle and Capalbo 2010). Continued efforts by groups such as the CGIAR centers, FAO, the International Institute for Applied Systems Analysis, and the UNFCCC Nairobi Program of Work to share their models and data and improve the capacity of those models to answer the critical questions about the impacts of adaptation and mitigation are an important research and knowledge management priority.

A second step is for the climate change community to learn from ongoing M\&E efforts in traditional development arenas (Hedger et al. 2008). There are a host of indicators in use to evaluate whether populations are food secure from all four perspectives of access, availability, utilization, and stability. Similarly, the quantity and variability of income from agriculture can also be tracked and measured, as can the efficiency of resource use in agricultural production. Development practitioners are also accustomed to using $\mathrm{M} \& \mathrm{E}$ as a tool to demonstrate accountability to donors. However, as less is known about the success of these interventions in relation to the uncertain impacts of climate change in the future, participatory tools such as outcome mapping with multiple stakeholders are necessary to collectively track progress and agree when a change of strategy is needed. This is particularly important given that current adaptation to economic risk or to enhance food security, for example, may not also guarantee adaptation to future climate change (Eriksen and O'Brien 2007; Eakin and Luers 2006).

A third and more difficult challenge is to build the learning networks across food systems and across levels of action and governance. Although many decisions about agricultural production and food security are made at the household level, those decisions are heavily influenced by higher-level institutions and policies. The use of a comprehensive food systems framework can help multiple players understand the impact of any given intervention in the context of a whole system and other interventions. As already mentioned, key institutions need to support learning networks and the establishment of shared databases.

Within the M\&E literature, reference is made to the difference between monitoring processes, outcomes, and impacts. We argue that monitoring all three is necessary to track behavioral change in food systems (Table 5.1). The causal pathways outlined for the necessary food system transitions suggest the processes that we think will achieve desired outcomes. We need to monitor how well those are implemented. Second, each of the interventions is hypothesized ex ante to achieve a certain outcome, which needs to be monitored. At the highest level, there are impacts on food security, incomes, and the environment, which also need to be monitored.

Table 5.1 Example of food system change metrics

\begin{tabular}{|c|c|c|c|c|}
\hline $\begin{array}{l}\text { Key food system } \\
\text { objective }\end{array}$ & $\begin{array}{l}\text { Strategies to } \\
\text { achieve this }\end{array}$ & $\begin{array}{l}\text { Process } \\
\text { indicator }\end{array}$ & $\begin{array}{l}\text { Outcome } \\
\text { indicator }\end{array}$ & $\begin{array}{l}\text { Impact } \\
\text { indicator }\end{array}$ \\
\hline \multirow[t]{2}{*}{$\begin{array}{l}\text { Enhance nutritional } \\
\text { value }\end{array}$} & $\begin{array}{l}\text { More nutritious food } \\
\text { grown }\end{array}$ & $\begin{array}{l}\text { Farmers' crop } \\
\text { choices change }\end{array}$ & $\begin{array}{l}\text { Foods with } \\
\text { greater nutritional } \\
\text { value harvested }\end{array}$ & $\begin{array}{l}\text { Diets contain } \\
\text { more nutritious } \\
\text { foods }\end{array}$ \\
\hline & $\begin{array}{l}\text { Price of nutritious } \\
\text { food reduced }\end{array}$ & $\begin{array}{l}\text { Pricing policies } \\
\text { implemented }\end{array}$ & $\begin{array}{l}\text { Households } \\
\text { purchase more } \\
\text { nutritious food }\end{array}$ & $\begin{array}{l}\text { Diets contain } \\
\text { more nutritious } \\
\text { foods }\end{array}$ \\
\hline \multirow[t]{2}{*}{$\begin{array}{l}\text { More efficient use of } \\
\text { scarce resources }\end{array}$} & Revise input prices & $\begin{array}{l}\text { Pricing policies } \\
\text { implemented }\end{array}$ & $\begin{array}{l}\text { Fertilizer use } \\
\text { modified }\end{array}$ & $\begin{array}{l}\text { Less fertilizer } \\
\text { waste }\end{array}$ \\
\hline & $\begin{array}{l}\text { Implement land } \\
\text { tenure }\end{array}$ & $\begin{array}{l}\text { Tenure policies } \\
\text { designed and } \\
\text { implemented }\end{array}$ & $\begin{array}{l}\text { Land tenure } \\
\text { more secure }\end{array}$ & $\begin{array}{l}\text { Land used more } \\
\text { efficiently }\end{array}$ \\
\hline
\end{tabular}

Source: Chesterman and Ericksen (2013). 


\section{Outcome Indicators: How Does Climate Change Affect What We Would Like to See?}

As has often been pointed out, climate change adds considerably to the challenges of sustainable development and global food security. As we have attempted to show, addressing those challenges in the face of climate change will require substantial behavioral changes at several different levels. At the same time, short- and long-term climate change imposes additional challenges on measuring changes in behavior and outcomes. In this subsection, we consider outcome indicators in relation to several features of climate change and the agricultural sector: risk-adjusted returns to agricultural systems; changes in transitory food insecurity in the wake of climate shocks; GHG emissions; and the problem of maladaptation.

\section{Risk-Adjusted Returns to Agricultural Systems}

Increasing frequencies of heat stress, drought, and flooding are projected for the rest of this century, and these are expected to have many adverse effects over and above the impacts due to changes in mean variables alone (IPCC 2012). Adaptation to climate change is sometimes most appropriately framed within the context of risk management: helping decisionmakers understand and deal with current levels of climate variability can provide a critical entry point to a consideration of longer-term changes not only in

climate variability but also in climate means. On the face of it, several ways exist by which to evaluate the variability of agricultural systems so that risk-adjusted returns can be quantified. In practice, however, doing so has real challenges. First, major difficulties exist relating to the uncertainty of climate projections and projected impacts over short to decadal time scales, and how this uncertainty is best treated in the search for social relevance. The climate models are still quite a way from being able to produce robust estimates of changes in variability into the future that we can use with any confidence. Second, appropriate cross-sectional and panel household/systems data may be difficult to come by in many situations, particularly information on inputs and farming practices, for example. Third, although various analytical frameworks exist for evaluating risk and making decisions under risk, the adequacy of some such frameworks (expected utility, for instance) in typical developing-country subsistenceorientated settings is a matter of debate. Moving from an agenda based on mean yields and income toward a more relevant one based on the variance of yields and income and threshold probabilities has clear implications for measurement, monitoring, and analysis: there is a major research agenda here, touching particularly on data collection methods, climate modeling and downscaling, and decision analytics and modeling.

\section{Changes in Transitory Food Insecurity in the Wake of Climate Shocks}

Food security has many dimensions, and no one indicator can capture all of them, so we need to develop a suite of indicators. A considerable literature exists concerning how food insecurity can be measured and how its various determinants can be assessed in relation to agricultural production of smallholders in developing countries. These include things such as the probability of falling below a food security threshold, a proxy of which is the probability of falling below a specific income, food consumption, or food expenditure threshold (Løvendal and Knowles 2005) and empirical approaches using household survey and climate data to establish the links between climate change, agricultural productivity, and household food consumption expenditure to estimate the likelihood of households falling below the food poverty line (Karfakis et al. 2011). FAO (2012c) provide a conceptual framework for looking at household food security changes after a climatic shock as the sum of benefits from safety nets and assets and from household-level adaptation (that is, productivity increases and reduced variability via adoption of particular practices, diversifying on-farm livelihood strategies, and diversifying income through offfarm activities). The issues surrounding the assessment of transitory food insecurity in the wake of shocks of different types (including climate) are dealt with in the Emergency Food Security Assessment Handbook (World Food Programme 2009), for example, and much is made of rapid data collection methods and use of proxies. As Barrett (2010) notes, measurement drives diagnosis and response, and considerable improvements are needed so that we can better identify food-insecure people and their targetable characteristics. This is particularly true if the nature of climate shocks will change with 
increased variability or long-term temperature increases. In this area the use of qualitative surveys of household behavior and perceptions can add a lot and enrich our knowledge and monitoring capacity beyond what can be understood with standardized quantitative indicators (Webb et al. 2006).

\section{GHG Emission Intensity per Unit of Agricultural Output}

Indicators for GHG mitigation are relatively easy to conceptualize but difficult to measure. As outlined earlier, agriculture is a net emitter of different GHGs, in particular $\mathrm{CO}_{2}$, methane, and $\mathrm{N}_{2} \mathrm{O}$, and these gases have different atmospheric lifetimes and radiative properties. The different global warming potential of these gases makes it possible to express emissions as tons of $\mathrm{CO}_{2}$ equivalent. Indicators for climate change mitigation revolve around measurement of the gases emitted or of the carbon sequestered. These measurements are not without several sources of uncertainty, including uncertainty over whether an agricultural carbon sequestration activity is actually implemented and over an accurate accounting of the land area involved, uncertainty arising from emission factors attributed to mitigation actions, particularly in heterogeneous agricultural landscapes, and uncertainty due to lack of scientific documentation of the impacts of management practices on non- $\mathrm{CO}_{2}$ emissions associated with carbon-sequestering processes (FAO 2013). Standardized methodologies and life-cycle assessment methods are key; otherwise, for example, results can be dependent on where the system boundary is drawn. Nevertheless, mitigation has substantial potential to diversify income sources for agricultural households in developing countries. There are many examples of household adaptation strategies that have mitigation co-benefits that could provide an extra source of income (one would be the use of agroforestry trees on-farm that provide highquality dry-season fodder, thus increasing livestock productivity and production, while at the same time sequestering carbon and providing a further potential source of income). Some mitigation activities, while providing additional income, may involve a trade-off in income from other agricultural activities (for example, funding for reducing emissions from deforestation, which could entail a decrease in agricultural land and farm income) (FAO 2010). This highlights the importance of analyses using robust tools capable of evaluating the synergies and trade-offs that may result, not only at the household level but at different scales too (at the landscape-watershed level, in relation to downstream impacts, for example; and at the national and regional levels, in relation to production shifts as an adaptation strategy, for instance). In all cases, it needs to be established that the public and private costs and benefits are distributed appropriately and in accord with government policy objectives.

\section{Indicators That Can Identify Potential Maladaptation Well in Advance}

As noted earlier in the paper, there is recent documentation of a case in Australia where transformative adaptation was undertaken and then reversed (Jakku et al. 2014). Moving away from a linear approach of "cascading uncertainty" (Challinor 2009) under which climate uncertainties dominate the inputs to decisionmaking toward a decision-centered approach in which climate change risk is recognized as only one driver (Willows and Connell 2003) may help to avoid large-scale and unnecessary change. But it seems likely that examples of maladaptation will become increasingly frequent, if there are limits to the number of low-regrets options that either are genuinely effective across a wide range of different, plausible futures or that are relatively insensitive to the uncertainties associated with the future climate. If adaptation is framed as a continuing process, this has considerable implications for monitoring, in attempts to identify divergences from desired outcomes as soon as possible. For large-scale, costly, or heavily time-lagged alternatives, it may be far better to prescreen them before embarking on such adaptations. Barnett and O'Neill (2010) identified five distinct types or pathways through which maladaptation may arise: increasing the emission of GHGs (for example, through the use of energyintensive adaptation options); disproportionately burdening the most vulnerable; implementing adaptation alternatives that have high opportunity costs; implementing alternatives that reduce people's incentives to adapt; and setting paths that limit the choices available to future generations (path dependency through technology lock-in or massive sunk costs, for example). For these reasons, we should build adaptationplanning frameworks on robust approaches that are as insensitive to uncertainties as possible, and planning responses need to be robust to social and political factors, which imply flexible approaches that protect the interests of different stakeholders (Macintosh 2012). 


\section{CONCLUSIONS: SUGGESTED PRIORITY ACTIONS FOR FAO AND CGIAR}

In this final section, we focus on what more FAO and CGIAR can and should do to enhance the effectiveness of our work supporting agricultural transitions to achieve food security under climate change. In previous sections we highlighted several areas where the two organizations are working on this issue, as well as four priority areas for immediate action: promoting agricultural technologies and innovations, strengthening local institutions, achieving coordinated and informed policies, and improving access to financing. Both organizations already conduct significant work in each of those priority areas, but we argue that given the urgency of responding to the challenge, a more coordinated, effective, and rapid support response from our two organizations is needed. To some extent this involves greater coordination between FAO and CGIAR, as well as enhancing the capacity for effective responses of each.

FAO provides technical support (including economic aspects) to countries in the design and implementation of agricultural development, food security, and natural resource management policies, strategies, and investments. Under the CSA approach, FAO has developed, climate change adaptation and mitigation are directly integrated into agricultural strategies, policies, and investments. However, much of the organization's work on agriculture and food security is still conducted without explicit recognition of climate change's impacts, and this is an area where much improvement can be made. FAO is also a forum for technical discussion on international policy issues relating food security, climate change, and agriculture that ensures policy coherence across food security (CFS) and climate change (UNFCCC), with the understanding that UNFCCC is the preferred intergovernmental arena for climate change negotiations. The HLPE report on climate change and food security in 2012 was a first step in the direction of improving coordination between agriculture, food security, and climate change policies, but much more is needed here as well. CGIAR undertakes research to reduce rural poverty, increase food security, improve human health and nutrition, and ensure more sustainable management of natural resources. CGIAR research programs, in close collaboration with hundreds of partner organizations, including national and regional research institutes, civil society organizations, academia, and the private sector, generate and disseminate knowledge, technologies, and policies for agricultural development. Together, FAO and CGIAR can combine their comparative advantages to support adoption of CSA practices and the policies, strategies, and investment that enable farmers to do so. Below, we make some suggestions for priority actions that FAO and CGIAR could undertake in three broad areas: better understanding of climate change impacts, improving tools to evaluate alternative actions, and facilitating innovation and strengthening the links between knowledge and action.

\section{Enhancing Our Understanding of How Climate Change Affects Agriculture}

With a few exceptions, the likely impacts of climate change on key staples and natural resources in developing countries are not understood in any great depth (FAO 2012d). There are many uncertainties as to how changes in temperature, rainfall, and atmospheric $\mathrm{CO}_{2}$ concentrations will interact in relation to agricultural productivity; the resultant changes in the incidence, intensity, and spatial distribution of important weeds, pests, and diseases are largely unknown. The impacts of climate change and increases in climate variability on agricultural systems and natural-resource-dependent households, as well as on food security and the future vulnerability of already-hungry people in the tropics and subtropics, are similarly unknown. At the same time, Ramirez-Villegas et al. (2013), evaluating the latest global climate models, estimate that at current rates of improvement, several decades' more work are required to improve regional temperature and precipitation simulations to the point where they could be used as direct inputs into agricultural impact models. The prognosis for robust evidence of quantifying changes in weather and climate variability over the short-to-medium term is thus gloomy, and the Ag R4D community will need to strengthen considerably links with the global change community if the climate model-based uncertainties are to be addressed adequately in impact studies. The inputs of CGIAR and FAO, along with many other partners, will be crucial if light is to be thrown on these issues (Thornton and Cramer 2012). 


\section{Evaluating Options}

We have highlighted risk management as one of the keys to improving resilience in agricultural households. The provision of guidelines for risk management under climate change, and practical advice on how they can be implemented, is a critical area of ongoing research. There are several ways in which FAO and CGIAR might develop this work in the future. These include increasing the understanding of the roles assets (physical, human, and social capital) and collective action play in managing climate risks, increasing understanding of how risk aversion affects farmers' decisionmaking in response to climate change, and increasing the engagement of civil society to bring about more participatory approaches to risk management and communication. FAO and CGIAR are already collaborating in the mitigation arena in several ways, and that work should be further developed. There are opportunities to facilitate multistakeholder action in implementing mitigation actions; more work is needed to quantify packages of mitigation practices in different situations and to evaluate the regional and global implications of such practices on resource use and commodity supply. There are substantial opportunities for developing measurement, reporting, and verification methodologies for mitigation projects as well as producing harmonized and robust guidelines for carbon footprinting, as well as providing support for pilot activities in countries that are keen to move forward in this area.

Another area we have highlighted is the need to assess technologies and policies in relation to multiple objectives and multiple temporal and spatial scales. This entails several elements: evaluating the trade-offs and synergies between the development outcomes of increased food security, enhanced rural livelihoods, and sustaining the environment; evaluating costs and benefits at different spatial scales and in relation to public and private bearers/recipients; and evaluating the issue of timing and avoiding shortterm gains that may be maladaptive in the longer term. Understanding the limits of different types of adaptation and the existence of thresholds beyond which transformation of livelihood systems may be required is an area to which CGIAR and FAO can contribute.

\section{Promoting Innovation and Linking Knowledge with Action}

As noted earlier, the engine that will drive sustained adaptation and transformation of agricultural systems is innovation: social, institutional, and technological. CGIAR and FAO are themselves in the process of transformation that offers increased potential for partnerships, inter-center collaboration, and transdisciplinary research. The explicit inclusion of development objectives at the system and program level creates considerable space for new approaches to be tested and implemented within FAO and CGIAR. For example, social learning approaches are critically relevant to achieving development goals, and they may be crucial in climate change adaptation research, mainly because of the need for researchers to connect with the local context (Gonsalves 2013). A rich array of social learning approaches exists (Harvey et al. 2012), some of which are already being used within FAO and CGIAR, and such efforts can be built on at the same time as methods for assessing their results are made more rigorous, in the effort to build a better evidence base for such approaches (Gonsalves 2013).

Scenario approaches have considerable power to engage governments, the private sector, researchers, civil society, and the media. Multistakeholder processes can explore key socioeconomic uncertainties and can be combined directly with climate scenarios to explore how human and biophysical future stressors interact to affect future food security, environments, and livelihoods. The combination of stakeholder perspectives with quantitative modeling can provide a linked science-policy interface. CGIAR has recently been working with scenario approaches, and planning for FAO-CGIAR collaboration in new regions is under way, in the context of adaptation to climate change. One challenge for the future is how to sustain continual engagement in such processes, so that we may realize the potential benefits of linking science with policy. 


\section{REFERENCES}

Agrawal, A., and N. Perrin. 2008. Climate Adaptation, Local Institutions, and Rural Livelihoods. IFPRI Working Paper W08I-6. Washington, DC: International Food Policy Research Institute.

Antle, J. M., and S. M. Capalbo. 2010. "Adaptation of Agricultural and Food Systems to Climate Change: An Economic Policy Perspective.” Applied Economic Perspectives and Policy 32: 386-416.

Antón J., S. Kimura, J. Lankoski, and A. Cattaneo. 2012. A Comparative Study of Risk Management in Agriculture under Climate Change. OECD Food, Agriculture, and Fisheries Papers 58. Paris: Organization for Economic Co-operation and Development Publishing.

Axelrod, R., and M. D. Cohen. 2000. Harnessing Complexity: Organizational Implications of a Scientific Frontier. New York: Free Press.

Barnett, J., and S. O’Neill. 2010. "Maladaptation.” Global Environmental Change 20: 211-213.

Barrett, C. B. 2010. "Measuring Food Insecurity." Science 327: 825-828.

Barrett, C. B., T. Reardon, and C. Webb. 2001. Nonfarm Income Diversification and Household Livelihood Strategies in Rural Africa: Concepts, Dynamics, and Policy Implications. Cornell University Working Paper. http://inequality.cornell.edu/publications/working papers/Barrett-Reardon-Webb_IntroFinal.pdf.

Beare, D. 2012. "Fisheries and Aquaculture." In Impacts of Climate Change on the Agricultural and Aquatic Systems and Natural Resources within the CGIAR's Mandate, edited by P. Thornton and L. Cramer, 56-67. CCAFS Working Paper 23. Copenhagen: CGIAR Research Program on Climate Change, Agriculture, and Food Security.

Bruinsma, J. 2009. The Resources Outlook to 2050-By How Much Do Land, Water, and Crop Yields Need to Increase by 2050? Accessed March 31, 2013. ftp://ftp.fao.org/docrep/fao/012/ak542e/ak542e00.pdf.

Brunette, M., L. Cabantous, S. Couture, and A. Stenger. 2012. "The Impact of Governmental Assistance on Insurance Demand under Ambiguity: A Theoretical Model and an Experimental Test." Theory and Decision. http://dx.doi.org/10.1007/s11238-012-9321-8.

Buchner, B., Falconer, A., Hervé-Mignucci, M., Trabacchi, C. 2012. The Landscape of Climate Finance 2012. Venice: Climate Policy Initiative.

Burney, J. A., S. J. Davis, and D. B. Lobell. 2010. "Greenhouse Gas Mitigation by Agricultural Intensification." Proceedings of the National Academy of Sciences 107 (26): 12052-12057.

Cavatassi, R., Lipper, L., Narloch, U. 2010. "Modern Variety Adoption and Risk Management in Drought Prone Areas: Insights from the Sorghum Farmers of Eastern Ethiopia.” Agricultural Economics 42: 279-292.

CGIAR. 2011. “A Strategy and Results Framework for the CGIAR.” Accessed March 31, 2013. library.cgiar.org/bitstream/handle/10947/2608/Strategy and_Results_Framework.pdf.

Challinor, A. J. 2009. "Towards the Development of Adaptation Options Using Climate and Crop Yield Forecasting at Seasonal to Multi-decadal Timescales." Environmental Science and Policy 12: 453-465.

Challinor, A. J., J. Watson, D. Lobell, M. Howden, D. Smith, and N. Chhetri. 2014. A Meta-analysis of Crop Yield under Climate Change and Adaptation." Nature Climate Change, forthcoming.

Chantarat, S., A. G. Mude, C. B. Barrett, and M. R. Carter. 2012. "Designing Index-Based Livestock Insurance for Managing Asset Risk in Northern Kenya." Journal of Risk and Insurance 80: 205-237.

Chaudhury, M., O. C. Ajayi, J. Hellin, and H. Neufeldt. 2011. Climate Change Adaptation and Social Protection in Agroforestry Systems: Enhancing Adaptive Capacity and Minimizing Risk of Drought in Zambia and Honduras. ICRAF Working Paper 137. Nairobi, Kenya: World Agroforestry Centre.

Chesterman, S., and P. Ericksen. 2013. Adaptation Indicators Used to Monitor Food Systems. CCAFS Working Paper 51. Copenhagen: CGIAR Research Program on Climate Change, Agriculture, and Food Security. 
Chimhowu, A., and P. Woodhouse. 2004. "Customary vs Private Property Rights? Dynamics and Trajectories of Vernacular Land Markets in Sub-Saharan Africa." Journal of Agrarian Change 6 (3): 346-371.

Clarke, H. 2008. "Classical Decision Rules and Adaptation to Climate Change." Australian Journal of Agricultural and Resource Economics 52 (4): 487-504.

Crespo, O., S. Hachigonta, and M. Tadross. 2011. "Sensitivity of Southern African Maize Yields to the Definition of Sowing Dekad in a Changing Climate." Climatic Change 106: 267-283.

Dalton, T. J., M. Yesuf, and L. Muhammad. 2011. "Demand for Drought Tolerance in Africa: Selection of Drought Tolerant Maize Seed Using Framed Field Experiments." Paper presented at the annual meeting of the Agricultural and Applied Economics Association, Pittsburgh, July 24-26.

De Janvry, A, and E. Sadoulet. 2010. "Agricultural Growth and Poverty Reduction: Additional Evidence.” World Bank Research Observer 25 (1): 1-20.

Dercon, S. 1996. "Risk, Crop Choice, and Savings." Economic Development and Cultural Change 44: 485-513.

Di Falco, S. and J.-P. Chavas. 2006. "Crop Genetic Diversity, Farm Productivity, and the Management of Environmental Risk in Rainfed Agriculture.” European Revue of Agricultural Economics 33 (3): 289-314.

Douthwaite, B. 2002. Enabling Innovation: A Practical Approach to Understanding and Fostering Technological Change. London: Zed Books.

Dryzek, J. S. 2009. "Democratization as Deliberative Capacity Building." Comparative Political Studies 42: 13791402.

Eakin, H., and A. L. Luers. 2006. "Assessing the Vulnerability of Social-Environmental Systems." Annual Review of Environment and Resources 31: 365-394.

Easterling, W. E., P. K. Aggarwal, P. Batima, K. M. Brander, L. Erda, S. M. Howden, A. Kirilenko, J. Morton, J.-F. Soussana, J. Schmidhuber, and F. N. Tubiello. 2007. "Food, Fibre, and Forest Products. Climate Change 2007: Impacts, Adaptation, and Vulnerability." Contribution of Working Group II to the Fourth Assessment Report of the Intergovernmental Panel on Climate Change, edited by M. L. Parry, O. F. Canziani, J. P. Palutikof, P. J. van der Linden, and C. E. Hanson, 273-313. Cambridge, UK: Cambridge University Press.

Ericksen, P., P. Thornton, A. Notenbaert, L. Cramer, P. Jones, and M. Herrero. 2011. Mapping Hotspots of Climate Change and Food Insecurity in the Global Tropics. CCAFS Report 5. Copenhagen: CGIAR Research Program on Climate Change, Agriculture, and Food Security.

Ericksen, P.J. 2008. “Conceptualizing Food Systems for Global Environmental Change Research.” Global Environmental Change 18: 234-245.

Ericksen, P. J., B. Stewart, J. Dixon, D. Barling, P. Loring, M. Anderson, and J. Ingram. 2010. "The Value of a Food Systems Approach." In Food Security and Global Environmental Change, edited by J. Ingram, P. Ericksen, and D. Liverman, 25-45. London: Earthscan.

Ericksen, S., and K. O’Brien. 2007. "Vulnerability, Poverty, and the Need for Sustainable Adaptation Measures." Climate Policy 7: 337-352.

Fafchamps, M., C. Udry, and K. Czukas. 1998. "Drought and Saving in West Africa: Are Livestock a Buffer Stock?" Journal of Development Economics 55: 273-305.

FAO (Food and Agriculture Organization of the United Nations). 2009. Food Security and Agricultural Mitigation in Developing Countries: Options for Capturing Synergies. Rome: FAO.

2010. Climate-Smart Agriculture: Policies, Practices, and Financing for Food Security, Adaptation, and Mitigation. Rome: FAO.

2011. Save and Grow: A Policymaker's Guide to the Sustainable Intensification of Smallholder Crop Production. Rome: FAO.

2012a. Developing a Climate-Smart Agriculture Strategy at the Country Level: Lessons from Recent Experience. Background Paper for the Second Global Conference on Agriculture, Food Security, and Climate Change, Hanoi, Vietnam, September 3-7. Rome: FAO. 
2012b. Towards the Future We Want: End Hunger and Make the Transition to Sustainable Agriculture and Food Systems. Policy paper for the Rio+20 Conference, June 13-22. Rome: FAO.

www.fao.org/docrep/015/an894e/an894e00.pdf.

- 2012c. Stability of Food Security in a Green Economy Environment. FAO Greening the Economy Working Paper 3. Rome: FAO. www.fao.org/fileadmin/user_upload/suistainability/papers/

Executive_Summaries_engl.pdf.

2012d. Building Resilience for Adaptation to Climate Change in the Agricultural Sector: Proceedings of a Joint FAO/OECD Workshop. Rome: FAO.

2012e. Climate-Smart Agriculture: Policies, Practices and Financing for Food Security, Adaptation and Mitigation. Rome: FAO.

-2013. Greenhouse Gas Emission from Livestock—Global Patterns and Mitigation Options. Rome: FAO.

Foley, J. A., N. Ramankutty, K. A. Brauman, E. S. Cassidy, J. S. Gerber, M. Johnston, N. D. Mueller, C. O'Connell, D. K. Ray, P. C. West, C. Balzer, E. M. Bennett, S. R. Carpenter, J. Hill, C. Monfreda, S. Polasky, J. Rockström, J. Sheehan, S. Siebert, D. Tilman, and D. P. M. Zaks. 2011. "Solutions for a Cultivated Planet." Nature 478: 337-342.

Foresight. 2011. The Future of Food and Farming. Final Project Report. London: Government Office for Science.

Garnett, T., and C. Godfray. 2012. Sustainable Intensification in Agriculture: Navigating a Course through Competing Food System Priorities. University of Oxford, UK: Food Climate Research Network and the Oxford Martin Programme on the Future of Food.

Gonsalves, J. F. 2013. A New Relevance and Better Prospects for Wider Uptake of Social Learning within the CGIAR. CCAFS Working Paper 37. Copenhagen: CGIAR Research Program on Climate Change, Agriculture, and Food Security.

Goodhue, R., and N. McCarthy. 2009. "Traditional Property Rights, Common Property, and Mobility in Semi-Arid African Pastoralist Systems." Environment and Development Economics 14: 29-50.

Gregory, P. J., S. N. Johnson, A. C. Newton, and J. S. I. Ingram. 2009. "Integrating Pests and Pathogens into the Climate Change/Food Security Debate.” Journal of Experimental Botany 60: 2827-2838.

Grothmann, T., and A. Patt. 2005. "Adaptive Capacity and Human Cognition: The Process of Individual Adaptation to Climate Change." Global Environmental Change 15: 199-213.

Hallegatte, S., A. Shah, R. Lempert, C. Brown, and S. Gill. 2012. Investment Decision Making under Deep Uncertainty: Application to Climate Change. World Bank Policy Research Working Paper 6193. Washington, DC: World Bank.

Halstead, P., and J. O'Shea, eds. 1989. Bad Year Economics: Cultural Responses to Risk and Uncertainty. New York: University of Cambridge Press.

Hansen, J., and K. Coffey. 2011. Agro-climate Tools for a New Climate-Smart Agriculture. Copenhagen: CGIAR Research Program on Climate Change, Agriculture, and Food Security.

Hansen, J., S. J. Mason, L. Sun, and A. Tall. 2011. "Review of Seasonal Climate Forecasting for Agriculture in SubSaharan Africa." Experimental Agriculture 47: 205-204.

Harvey, B., J. Ensor, L. Carlile, B. Garside, Z. Patterson, and L. O. Naess. 2012. Climate Change Communication and Social Learning - Review and Strategy Development for CCAFS. CCAFS Working Paper 22. Copenhagen: CGIAR Research Program on Climate Change, Agriculture, and Food Security.

Havlík, P., U. A. Schneider, E. Schmid, H. Böttcher, S. Fritz, R. Skalský, K. Aoki, S. D. Cara, G. Kindermann, F. Kraxner, S. Leduc, I. McCallum, A. Mosnier, T. Sauer, and M. Obersteiner. 2011. "Global Land-Use Implications of First and Second Generation Biofuel Targets.” Energy Policy 39 (10): 5690-5702.

Hedger, M. M., T. Mitchell, J. Leavy, M. Greeley, A. Downie, and L. Horricks. 2008. Desk Review: Evaluation of Adaptation to Climate Change from a Development Perspective. Brighton, UK: Institute of Development Studies. 
Heltberg, R., P. B. Siegel, and S. L. Jorgensen. 2009. "Addressing Human Vulnerability to Climate Change: Toward a 'No-Regrets' Approach.” Global Environmental Change 19 (1): 89-99.

Herrero, M., R. T. Conant, P. Havlik, A. N. Hristov, P. Smith, P. Gerber, M. Gill, K. Butterbach-Bahl, B. Henderson, and P. K. Thornton. 2014. "Greenhouse Gas Mitigation Potentials in the Livestock Sector." Nature Climate Change. Forthcoming.

Herrero, M., P. K. Thornton, A. M. Notenbaert, S. Wood, S. Msangi, H. A. Freeman, D. Bossio, J. Dixon, M. Peters, J. van de Steeg, J. Lynam, P. P. Rao, S. Macmillan, B. Gerard, J. McDermott, C. Seré, and M. Rosegrant. 2010. "Smart Investments in Sustainable Food Production: Revisiting Mixed Crop-Livestock Systems." Science 327: 822-825.

Hertel, T. W., and S. D. Rosch. 2010. "Climate Change, Agriculture, and Poverty." Applied Economic Perspectives and Policy 32 (3): 355-385.

HLPE (High Level Panel of Experts). 2012. Food Security and Climate Change: A Report by the High Level Panel of Experts on Food Security and Nutrition. Rome: Committee on World Food Security.

Howden, S. M., S. J. Crimp, and R. N. Nelson. 2010. “Australian Agriculture in a Climate of Change.” In Managing Climate Change, edited by I. Jubb, P. Holper, and W. Cai, 101-111. Melbourne: Commonwealth Scientific and Industrial Research Organisation.

Howden, S. M., J. F. Soussana, F. N. Tubiello, N. Chhetri, M. Dunlop, and H. M. Meinke. 2007. “Adapting Agriculture to Climate Change." Proceedings of the National Academy of Sciences 104: 19691-19696.

IFAD (International Fund for Agricultural Development). 2011. Rural Poverty Report 2011. New Realities, New Challenges: New Opportunities for Tomorrow's Generation. Rome: IFAD.

IPCC (Intergovernmental Panel on Climate Change). 2012. Managing the Risks of Extreme Events and Disasters to Advance Climate Change Adaptation. A Special Report of Working Groups I and II of the Intergovernmental Panel on Climate Change. Cambridge, UK, and New York: Cambridge University Press.

Jakku, E., P. J. Thorburn, E. Mendham, N. A. Marshall, K. Moon, and S. M. Howden. 2014. "Learning the Hard Way: A Case Study of an Agricultural Company Undertaking Transformational Adaptation to Climate Change." Climatic Change. Forthcoming.

Jones, P. G., and P. K. Thornton. 2003. "The Potential Impacts of Climate Change in Tropical Agriculture: The Case of Maize in Africa and Latin America in 2055." Global Environmental Change 13: 51-59.

Kandulu, J. M., B. A. Bryan, D. King, and J. D. Connor. 2012. "Mitigating Economic Risk from Climate Variability in Rain-Fed Agriculture through Enterprise Mix Diversification." Ecological Economics 79: 105-112.

Karfakis, P., M. Knowles, M. Smulders, and J. Capaldo. 2011. Effects of Global Warming on Vulnerability to Food Insecurity in Rural Nicaragua. ESA (Agricultural Development Economics Division) Working Paper 1118. Rome: Food and Agriculture Organization.

Kates, R. W., W. R. Travis, and T. J. Wilbanks. 2012. "Transformational Adaptation When Incremental Adaptations to Climate Change Are Insufficient." Proceedings of the National Academy of Sciences 109: 7156-7161.

Kok, K., D. S. Rothman, and N. Patel. 2006. "Multi-scale Narratives from an IA Perspective. Part I. European and Mediterranean Scenario Development." Futures 38 (3): 261-284.

Kok, K., M. van Vliet, I. Bärlund, A. Dubel, and J. Sendzimir. 2011. "Combining Participative Backcasting and Exploratory Scenario Development: Experiences from the SCENES Project.” Technological Forecasting and Social Change 78 (5): 835-851.

Kremen, C., and A. Miles. 2012. "Ecosystem Services in Biologically Diversified versus Conventional Farming Systems: Benefits, Externalities, and Trade-Offs." Ecology and Society 17 (4): 40.

Laliberté, E., J. A. Wells, F. DeClerck, D. J. Metcalfe, C. P. Catterall, C. Queiroz, I. Aubin, S. P. Bonser, Y. Ding, J. M. Fraterrigo, S. McNamara, J. W. Morgan, D. S. Merlos, P. A. Vesk, and M. M. Mayfield. 2010. "LandUse Intensification Reduces Functional Redundancy and Response Diversity in Plant Communities." Ecology Letters 13: 76-86. 
Locatelli, B., T. Sunderland, C. Padoch, D. Murdiyarso, and L. Verchot. 2012. "Forests." In Impacts of Climate Change on the Agricultural and Aquatic Systems and Natural Resources within the CGIAR's Mandate, edited by P. Thornton and L. Cramer, 182-188. CCAFS Working Paper 23. Copenhagen: CGIAR Research Program on Climate Change, Agriculture, and Food Security.

Løvendal, C. R., and M. Knowles. 2005. Tomorrow's Hunger: A Framework for Analysing Vulnerability to Food Insecurity. ESA (Agricultural Development Economics Division) Working Paper 05-07. Rome: Food and Agriculture Organization.

Lybbert, T. J., C. B. Barrett, S. Desta, and D. L. Coppock. 2004. "Stochastic Wealth Dynamics and Risk Management among a Poor Population.” Economic Journal 114: 750-777.

Macintosh, A. 2012. "Coastal Climate Hazards and Urban Planning: How Planning Responses Can Lead to Maladaptation." Mitigation and Adaptation Strategies for Global Change. doi:10.1007/s11027-012-9406-2.

Malhotra, A., J. Schulte, P. Patel, and P. Patesch. 2009. Innovation for Women's Empowerment and Gender Equality. International Center for Research on Women, Washington DC.

Marx, S. M., Weber, E. U., Orlove, B. S., Leiserowitz, A., Krantz, D. H., Roncoli, C., Phillips, J. 2007. "Communication and Mental Processes: Experiential and Analytic Processing of Uncertain Climate Information." Global Environmental Change 17 (1): 47-58.

McCarthy, N., L. Lipper, and G. Branca. 2011. Climate-Smart Agriculture: Smallholder Adoption and Implications for Climate Change Adaptation and Mitigation. MICCA Working Paper 4. Rome: Food and Agriculture Organization of the United Nations.

McCarthy, N., B. Swallow, M. Kirk, and P. Hazell, eds. 2000. Property Rights, Risk, and Livestock Development in Africa. Nairobi, Kenya: International Food Policy Research Institute and International Livestock Research Institute.

McOmber, C., A. Panikowski, S. McKune, W. Bartels, and S. Russo. 2013. Investigating Climate Information Services through a Gendered Lens. CCAFS Working Paper 42. Copenhagen: CGIAR Research Program on Climate Change, Agriculture, and Food Security.

Meinzen-Dick, R., A. Knox, F. Place, and B. Swallow, eds. 2002. Innovation in Natural Resource Management: The Role of Property Rights and Collective Action in Developing Countries. Baltimore: Johns Hopkins University Press.

Meinzen-Dick, R., H. Markelova, and K. Moore. 2010. The Role of Collective Action and Property Rights in Climate Change Strategies. CAPRi Policy Brief 7. Washington, DC: CGIAR Systemwide Program on Collective Action and Property Rights.

Millennium Ecosystem Assessment. 2005. Ecosystems and Human Well-Being. Vol. 2, Scenarios. Washington, DC: Island Press.

Miura, K., H. Kanno, T. Sakurai. 2012. "Rainfall Shock and Livestock Transactions in Rural Zambia: An Empirical Examination Using High Frequency Panel Data.” Paper presented at the Asian Historical Economics Conference, Kunitachi, Tokyo, September 13-15.

MRF (Mary Robinson Foundation). 2013. "Principles of Climate Justice.” Accessed June 28, 2013. www.mrfcj.org/about/principles.html.

Nelson, G.C., van der Mensbrugghe, D. 2013. "Public Sector Agricultural Research Priorities for Sustainable Food Security: Perspectives from Plausible Scenarios." Background paper for the conference "Food Security Futures: Research Priorities for the 21st Century," April 11-12, 2013, Dublin.

Park, S. E., N. A. Marshall, E. Jakku, A. M. Dowd, S. M. Howden, E. Mendham, and A. Fleming. 2012. "Informing Adaptation Responses to Climate Change through Theories of Transformation." Global Environmental Change 22: 115-126.

Patt, A. G., and G. Schröter. 2008. "Perceptions of Climate Risk in Mozambique: Implications for the Success of Adaptation Strategies." Global Environmental Change 18: 458-467. 
Pelling, M., and C. High. 2005. "Understanding Adaptation: What Can Social Capital Offer Assessments of Adaptive Capacity?" Global Environmental Change 15: 308-319.

Pelling, M., C. High, J. Dearing, and D. Smith. 2008. "Shadow Spaces for Social Learning: A Relational Understanding of Adaptive Capacity to Climate Change within Organisations." Environment and Planning A 40: 867-884.

Place, F., Meybeck, A. 2013. "Food Security and Sustainable Resource Use: What are the Resource Challenges to Food Security?" Background paper for the conference "Food Security Futures: Research Priorities for the 21 st Century," April 11-12, 2013, Dublin.

Popp, A., H. Lotze-Campen, and B. Bodirsky. 2010. "Food Consumption, Diet Shifts, and Associated non- $\mathrm{CO}_{2}$ Greenhouse Gases from Agricultural Production.” Global Environmental Change 20: 451-462.

Quiggin, J., and J. Horowitz. 2003. "Costs of Adjustment to Climate Change.” Australian Journal of Agricultural and Resource Economics 47: 429-446.

Ramirez-Villegas, J., A. C. Challinor, P. K. Thornton, and A. Jarvis. 2013. "Implications of Regional Improvement in Global Climate Models for Agricultural Impacts Research." Environmental Research Letters 8: 024018.

Reid, R., D. Nkedianye, M. Said, D. Kaelo, M. Neselle, O. Makui, L. Onetu, S. Kiruswa, N. O. Kamuaro, and P. Kristjanson. 2009. "Evolution of Models to Support Community and Policy Action with science: Balancing Pastoral Livelihoods and Wildlife Conservation in Savannas of East Africa." Proceedings of the National Academy of Sciences, Early Edition. doi: 10.1073/pnas.0900313106

Rickards, L., and S. M. Howden. 2012. "Transformational Adaptation: Agriculture and Climate Change." Crop and Pasture Science 63: 240-250.

Ricketts, T. H. 2001. “Conservation Biology and Biodiversity." Encyclopedia of Life Sciences (eLS). London: MacMillan Reference Ltd.

Rockström, J., M. Falkenmark, L. Karlberg, H. Hoff, S. Rost, and D. Gerten. 2009. "Future Water Availability for Global Food Production: The Potential of Green Water for Increasing Resilience to Global Change." Water Resources Research 45 (7): W00A12.

Rodell, M., I. Velicogna, and J. S. Famiglietti. 2009. "Satellite-Based Estimates of Groundwater Depletion in India." Nature 460: 999-1002.

Rosegrant, M. W., M. Agcaoili-Sombilla, and N. D. Perez. 1995. Food Projections to 2020: Implications for Investment. Washington, DC: International Food Policy Research Institute.

Rosegrant, M.W., M. Fernandez, A. Sinha, J. Alder, H. Ahammad, C. de Fraiture, B. Eickhout, J. Fonseca, J. Huang, O. Koyama, A. M. Omezzine, P. Pingali, R. Ramirez, C. Ringler, S. Robinson, P. Thornton, D. van Vuuren, and H. Yana-Shapiro. 2009. "Looking into the Future for Agriculture and AKST (Agricultural Knowledge Science and Technology)." In Agriculture at a Crossroads, edited by B. D. McIntyre, H. R. Herren, J. Wakhungu, and R. T. Watson, 307-376. Washington, DC: Island Press.

Rufino, M. C., P. K. Thornton, S. K. Ng'ang'a, I. Mutie, P. G. Jones, M. T. van Wijk, and M. Herrero. 2013. "Transitions in Agro-pastoralist Systems of East Africa: Impacts on Food Security and Poverty." Agriculture, Ecosystems, and Environment 179: 215-230.

Sarapura, S. 2009. "Innovating Agriculture through Gender Lenses.” PhD Dissertation, School of Environmental Design and Rural Development, University of Guelph, Guelph, Canada.

SAVANET (The Savannah Young Farmers Network) 2013. "Introduction to SAVANET." Accessed January 13, 2014. http://savanet-ghana.blogspot.co.uk/2013/12/introduction-to-savannah-young-farmers.html.

Seo, S. N. 2012. "Decision Making under Climate Risks: An Analysis of Sub-Saharan Farmers' Adaptation Behaviors." Weather, Climate, and Society 4: 285-299.

Smith, P., H. Heberl, A. Popp, K.-H. Erb, C. Lauk, R. Harper, F. Tubiello, A. De Pinto, M. Jafari, S. Sohi, O. Masera, H. Bottcher, G. Berndes, M. Bustamante, H. Ahammad, H. Clark, H. Dong, E. Elsiddig, C. Mbow, N. Ravindranath, C. Rice, C. Abad, A. Romanovskaya, F. Sperling, M. Herrero, J. House, and S. Rose. 
2013. "How Much Land Based Greenhouse Gas Mitigation Can Be Achieved without Compromising Food Security and Environmental Goals?" Global Change Biology 19 (8): 2285-2302.

Smith, P., D. Martino, Z. Cai, D. Gwary, H. Janzen, P. Kumar, B. McCarl, S. Ogle, F. O’Mara, C. Rice, B. Scholes, O. Sirotenko, M. Howden, T. McAllister, G. Pan, V. Romanenkov, U. Schneider, S. Towprayoon, M. Wattenbach, and J. Smith. 2008. "Greenhouse Gas Mitigation in Agriculture." Philosophical Transactions of the Royal Society B 363: 789-813.

Sunderland, T. C. H. 2011. “Food Security: Why Is Biodiversity Important?” International Forestry Review 13 (3): $265-274$.

Tall, A., S. J. Mason, M. van Aalst, P. Suarez, Y. Ait-Chellouche, A. A. Diallo, and L. Braman. 2012. "Using Seasonal Climate Forecasts to Guide Disaster Management: The Red Cross Experience during the 2008 West Africa Floods.” International Journal of Geophysics doi:10.1155/2012/986016.

Thornton, P., and L. Cramer, eds. 2012. Impacts of Climate Change on the Agricultural and Aquatic Systems and Natural Resources within the CGIAR's Mandate. CCAFS Working Paper 23. Copenhagen: CGIAR Research Program on Climate Change, Agriculture, and Food Security. www.ccafs.cgiar.org.

van Etten, J. 2011. "Crowdsourcing Crop Improvement in Sub-Saharan Africa: A Proposal for a Scalable and inclusive approach to food security.” IDS Bulletin 42 (4): 102-110.

van Notten, P. W. F., J. Rotmans, M. B. A. van Asselt, and D. S. Rothman. 2003. "An Updated Scenario Typology.” Futures 35 (5): 423-443.

Van Vuren, D. P., W. O. Ochola, S. Riha, M. Giampietro, H. Ginzo, T. Henrichs, S. Hussain, K. Kok, M. Makhura, M. Mirza, K. P. Palanisama, C. R. Ranganathan, S. Ray, C. Ringler, A. Rola, H. Westhoek, and M. Zurek. 2009. "Outlook on Agricultural Change and Its Drivers." In Agriculture at a Crossroads, edited by B. D. McIntyre, H. R. Herren, J. Wakhungu, and R. T. Watson, 255-305. Washington, DC: Island Press.

Vernooy, R. 2012. "Plant Breeders Respond to Climate-Related Stresses in Multiple Ways". Accessed January 13, 2014. http://ccafs.cgiar.org/blog/plant-breeders-respond-climate-related-stresses-variousways\#.UtQ6flKYabg.

Vervoort, J., P. K. Thornton, P. Kristjanson, W. Förch, P. Ericksen, K. Kok, J. S. I. Ingram, M. Herrero, A. Palazzo, A. Helfgott, A. Wilkinson, and P. Havlik. 2014. "Food Systems Futures: Towards Adaptation Pathways across Multiple Dimensions and Levels." Global Environmental Change. Forthcoming.

Warner, K., T. Afifi, K. Henry, T. Rawe, C. Smith, and A. D. Sherbinin. 2012. Where the Fain Falls: Climate Change, Food and Livelihood Security, and Migration. An Eight-Country Study to Understand Rainfall, Food Security, and Human Mobility. United Nations University, Institute for Environment and Human Security, Bonn.

Webb, P., J. Coates, F. A. Frongillo, B. L. Rogers, A. Swindale, and P. Bilinsky. 2006. "Measuring Household Food Insecurity: Why It Is So Important and Yet So Difficult to Get Right." Journal of Nutrition 136: 1404-1408.

Wilkinson, A., and E. Eidinow. 2008. "Evolving Practices in Environmental Scenarios: A New Scenario Typology." Environmental Research Letters 3 (4): 045017.

Willows, R., and R. Connell, eds. 2003. Climate Adaptation: Risk, Uncertainty, and Decision-Making. Oxford, UK: UKCIP.

World Bank. 2008. World Development Report 2008: Agriculture for Development. Washington, DC. 2010. World Development Report 2010: Development and Climate Change. Washington, DC.

World Food Programme. 2009. Emergency Food Security Assessment Handbook, 2nd ed. Rome.

Ziervogel, G., S. Bharwani, and T. E. Downing. 2006. "Adapting to Climate Variability: Pumpkins, People, and Policy." Natural Resources Forum 30: 294-305.

Zomer, R. J., A. Trabucco, R. Coe, and F. Place. 2009. Trees on Farm: Analysis of Global Extent and Geographical Patterns of Agroforestry. ICRAF Working Paper 89. Nairobi, Kenya: World Agroforestry Centre. 



\section{RECENT IFPRI DISCUSSION PAPERS}

\section{For earlier discussion papers, please go to www.ifpri.org/pubs/pubs.htm\#dp. All discussion papers can be downloaded free of charge.}

1339. Public-sector agricultural research priorities for sustainable food security: Perspectives from plausible scenarios. Gerald C. Nelson and Dominique van der Mensbrugghe, 2014.

1338. Migration, local off-farm employment, and agricultural production efficiency: Evidence from China. Jin Yang, Hui Wang, Songqing Jin, Kevin Chen, Jeffrey Riedinger, and Peng Chao, 2014.

1337. Farmers' preferences for climate-smart agriculture: An Assessment in the Indo-Gangetic Plain. Garima Taneja, Barun Deb Pal, Pramod K. Joshi, Pramod K. Aggarwal, N. K. Tyagi, 2014.

1336. An empirical examination of the dynamics of varietal turnover in Indian wheat. Vijesh V. Krishna, David J. Spielman, Prakashan C. Veettil, and Subash Ghimire, 2014.

1335. Agricultural policy processes and the youth in Malawi. Mariam A. T. J. Mapila, 2014.

1334. Can cash transfers promote the local economy?: A case study for Cambodia. Stephanie Levy and Sherman Robinson, 2014.

1333. Gender, control, and crop choice in northern Mozambique. Alan de Brauw, 2014.

1332. Employment risk and job-seeker performance. Susan Godlonton, 2014.

1331. Food prices and poverty reduction in the long run. Derek Headey, 2014.

1330. Impact of Ghana's Agricultural Mechanization Services Center Program. Samuel Benin, 2014.

1329. Aid effectiveness: How is the L'Aquila Food Security Initiative doing? Samuel Benin, 2014.

1328. Improved dairy cows in Uganda: Pathways to poverty alleviation and improved child nutrition. Nassul Kabunga, 2014.

1327. A comparative analysis of global cropping systems models and maps. Weston Anderson, Liangzhi You, Stanley Wood, Ulrike Wood-Sichra, and Wenbin Wu, 2014.

1326. Population pressure and livelihood dynamics: Panel evidence from Bangladesh. Shahidur Rashid, Nigussie Tefera, Solomon Lemma, and Mohammad Yunus, 2014.

1325. Changing sources of growth in Indian Agriculture: Implications for regional priorities for accelerating agricultural growth. Pratap S. Birthal, Pramod K. Joshi, Digvijay S. Negi, and Shaily Agarwal, 2014.

1324. Risk and Ambiguity Preferences and the Adoption of New Agricultural Technologies: Evidence from Field Experiments in Rural India. Patrick S. Ward and Vartika Singh, 2014.

1323. Land, Assets, and Livelihoods: Gendered Analysis of Evidence from Odisha State in India. Vivien Savath, Diana Fletschner, Amber Peterman, and Florence Santos, 2014.

1322. Exploring local perceptions of climate change impact and adaptation in rural Bangladesh. Peter Davis and Snigdha Ali, 2014.

1321. Closing the gender asset gap: Learning from value chain development in Africa and Asia. Agnes R. Quisumbing, Deborah Rubin, Cristina Manfre, Elizabeth Waithanji, Mara van den Bold, Deanna Olney, and Ruth Meinzen-Dick, 2014.

1320. The political economy of Zambia's recovery: Structural change without transformation? Danielle Resnick and James Thurlow, 2014.

1319. The impact of Bolsa Familia on schooling: Girls' advantage increases and older children gain. Alan de Brauw, Daniel O. Gilligan, John Hoddinott, and Shalini Roy, 2014.

1318. Exploring strategic priorities for regional agricultural research and development investments in Southern Africa. Michael Johnson, Samuel Benin, Liangzhi You, Xinshen Diao, Pius Chilonda, and Adam Kennedy, 2014.

1317. How do intrahousehold dynamics change when assets are transferred to women?: Evidence from BRAC's Challenging the Frontiers of Poverty Reduction-Targeting the Ultra Poor Program in Bangladesh. Narayan Das, Rabeya Yasmin, Jinnat Ara, Md. Kamruzzaman, Peter Davis, Julia A. Behrman, Shalini Roy, and Agnes R. Quisumbing, 2013.

1316. Is there an app for that?: The impact of community knowledge workers in Uganda. Bjorn Van Campenhout, 2013. 


\section{INTERNATIONAL FOOD POLICY}

RESEARCH INSTITUTE

www.ifpri.org

IFPRI HEADQUARTERS

2033 K Street, NW

Washington, DC 20006-1002 USA

Tel.: +1-202-862-5600

Fax: +1-202-467-4439

Email: ifpri@cgiar.org 